\title{
Neurogenetic basis for circadian regulation of metabolism by the hypothalamus
}

\author{
Jonathan Cedernaes, Nathan Waldeck, and Joseph Bass \\ Department of Medicine, Feinberg School of Medicine, Northwestern University, Chicago, Illinois 60611, USA
}

Circadian rhythms are driven by a transcription-translation feedback loop that separates anabolic and catabolic processes across the Earth's 24-h light-dark cycle. Central pacemaker neurons that perceive light entrain a distributed clock network and are closely juxtaposed with hypothalamic neurons involved in regulation of sleep/wake and fast/feeding states. Gaps remain in identifying how pacemaker and extrapacemaker neurons communicate with energy-sensing neurons and the distinct role of circuit interactions versus transcriptionally driven cellautonomous clocks in the timing of organismal bioenergetics. In this review, we discuss the reciprocal relationship through which the central clock drives appetitive behavior and metabolic homeostasis and the pathways through which nutrient state and sleep/wake behavior affect central clock function.

Molecular dynamics of the circadian clock

Solar light has provided energy on a daily basis throughout evolution, driving the development of internal clock systems that use similar molecular mechanisms across distant phyla (Ouyang et al. 1998). In mammals, the clock network consists of transcription-translation feedback loops (TTFLs) composed of two basic helix-loop-helix factors (CLOCK/BMAL1) in the forward limb-which activate their own repressors (PERs/CRYs) in the negative limb-in addition to a reinforcing short feedback loop controlling the transcription of Bmal1 (REVERBs/RORs) (Kornmann et al. 2007; Gerhart-Hines et al. 2013). Discovery of the molecular components of the circadian clock led to the finding that tissue-specific transcriptional and posttranscriptional rhythms play a critical role in energy utilization and storage in anticipation of the light-dark cycle. Many additional regulators of the core clock have been discovered over the past $30 \mathrm{yr}$, and these are extensively discussed in other reviews (Mohawk et al. 2012; Takahashi 2017). Direct targets of CLOCK/BMAL1 include genes with E-box and D-box elements. The latter

[Keywords: circadian; diabetes; hypothalamus; obesity]

Corresponding author: j-bass@northwestern.edu

Article is online at http://www.genesdev.org/cgi/doi/10.1101/gad.328633. 119. include the transcription factors (TFs) DBP, TEF, and HLF as well as the repressor E4BP4 (often referred to as NFIL3 in immune cells), all of which are enriched in endocrine tissues (Takahashi 2017). REVERBs/RORs control not only expression of BMAL1 but also that of E4BP4. All three transcriptional feedback loops (CLOCK/BMAL1, REVERBs/RORs, and D-box-binding elements) participate in rhythmic transcriptional control of additional cycling genes, which, as an ensemble, are often referred to as clock-controlled genes (Fig. 1; Takahashi 2017).

Nucleocytoplasmic transport of clock components corresponds with distinct activation and repression phases of the circadian cycle. Following transcriptional activation by CLOCK/BMAL1, Per and Cry mRNAs undergo translation in the cytoplasm, and PER shuttles between the nucleus and cytoplasm until it binds to CRY, which seeds the formation of a macromolecular repressor complex $>1$ MDa in mass (Brown et al. 2005; Kim et al. 2014). In addition to other epigenetic regulators (Gallego and Virshup 2007; Lim and Allada 2013; Zhang et al. 2013), the serine/threonine kinase casein kinase-1 (CK1) interacts with this PER complex, causing a series of phosphorylation events. Following its nuclear entry, the PER complex binds to chromatin and represses CLOCK/BMAL1 (Takahashi 2017). PER phosphorylation also contributes to its ubiquitin-mediated degradation (Eide et al. 2005; Aryal et al. 2017), while CRY degradation involves FBXL3 and FBXL21 within nucleus and cytoplasm, respectively (Busino et al. 2007; Godinho et al. 2007; Siepka et al. 2007; Yoo et al. 2013). Mutations in PER that alter its phosphorylation state lead to familial advanced sleep phase syndrome (FASPS) (Toh et al. 2001); CRY mutations lead to delayed sleep and altered period in humans (Patke et al. 2017), similar to mutations in Fbxl3/21 in mice; and mutations of the $C k 1$ ortholog in hamsters shorten period length and increase energy expenditure (Lowrey et al. 2000).

The molecular clock is expressed in nearly all cells of the body and exhibits both tissue-specific function and entrainment by hormonal, neuroendocrine, heat, and

(C) 2019 Cedernaes et al. This article is distributed exclusively by Cold Spring Harbor Laboratory Press for the first six months after the full-issue publication date (see http://genesdev.cshlp.org/site/misc/terms.xhtml). After six months, it is available under a Creative Commons License (Attribution-NonCommercial 4.0 International), as described at http://creativecommons.org/licenses/by-nc/4.0/. 


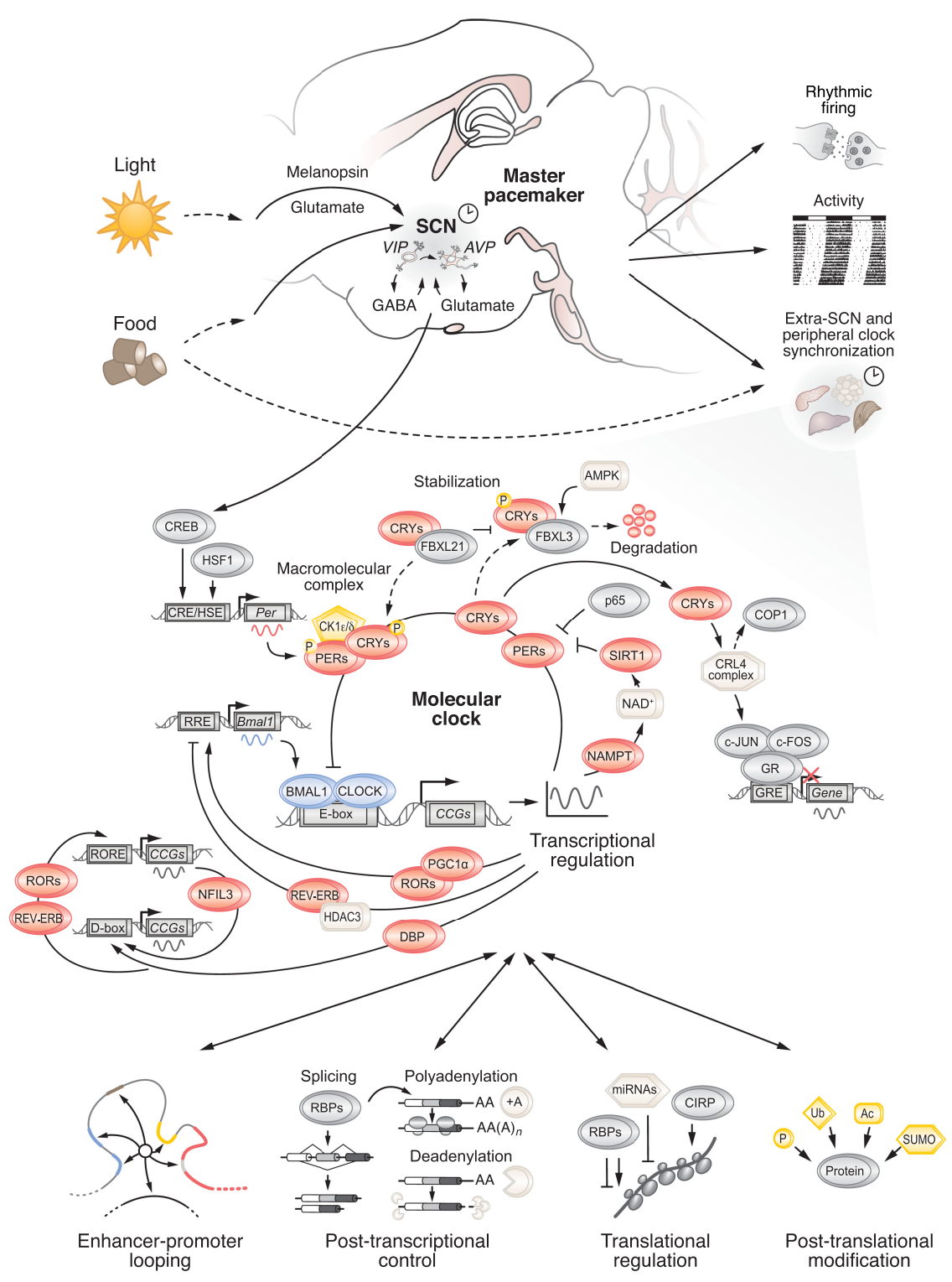
tion. These reciprocal interactions allow circadian rhythms to adapt to changes in organismal metabolic state, and changes in some of these mechanisms (e.g., $\mathrm{NAD}^{+}$) have been implicated in the age-associated decline in circadian function (Chang and Guarente 2013).

metabolite signals (Zhang et al. 2014b; Takahashi 2017). Indeed, recent interrogation of chromatin binding by the core circadian repressor REV-ERBa in brain, liver, and white adipose tissue (WAT) has revealed that the coordination of molecular rhythms across tissues requires the collaboration of core clock factors with tissue-specific TFs (Fang et al. 2014; Zhang et al. 2015). In addition to the regulation of rhythmic gene expression along chromosomes in cis, circadian mechanisms are also driven by interactions in trans across spatially distant areas of the genome. For example, circular chromosome conformation capture $(4 \mathrm{C})$ in the liver recently led to the identification of intronic enhancer elements in the Cry1 gene that, when ablated, resulted in a shortened daily locomo-

Figure 1. Sensory integration of light and food cues by the hypothalamic molecular clock. The master pacemaker neurons of the suprachiasmatic nucleus (SCN) are responsible for synchronizing downstream extra-SCN and peripheral clocks to the external light-dark cycle. Vasoactive intestinal peptide (VIP)-expressing cells within the SCN receive photic input from melanopsin-expressing retinal cells in the retinohypothalamic tract that release glutamate and pituitary adenylate cyclase-activating polypeptide (PACAP), which leads to the phosphorylation of cAMP response element (CRE)-binding (CREB) protein and rhythmic activation of immediate early genes and expression of Period (Per) genes. The rhythmic firing of VIP neurons in turn entrains arginine vasopressin (AVP)-expressing cells within the SCN and downstream extraSCN and peripheral oscillators. Similar light-mediated regulation of the SCN in control of circadian rhythms is thought to occur in humans (Schmidt et al. 2009; Vimal et al. 2009; Wang et al. 2015; McGlashan et al. 2018). The middle panel depicts the core molecular clock machinery present in SCN, extra-SCN, and all peripheral cells in addition to highlighting other signals conveyed through metabolic and inflammatory signaling pathways and TFs, such as SIRT1/ nicotinamide adenine dinucleotide $\left(\mathrm{NAD}^{+}\right) /$ NAMPT, AMP-dependent kinase (AMPK), and PGCla (Liu et al. 2007; Lamia et al. 2009; Ramsey et al. 2009; Guan et al. 2018; Hong et al. 2018), which participate in the fine-tuning of the 24-h oscillations of the core clock machinery. Regulation of the molecular clock occurs through multiple epigenetic and posttranscriptional mechanisms, such as enhancer and promoter chromatin looping (Kim et al. 2018; Mermet et al. 2018), phosphorylation of the macromolecular repressor complex (PER and CRY proteins) (Brown et al. 2005; Kim et al. 2014), , which in turn can influence core clock func- 


\section{Circadian regulation of neuronal activity-dependent transcription and translation}

As postmitotic cells, central nervous system (CNS) neurons are unable to grow and adapt across cell generations like other cell types in the body; they must instead rely on genomic alterations and synaptic formations to both retain vital information and respond to new stimuli (Yap and Greenberg 2018). Behaviorally induced alterations in transcriptional rhythms within neurons have been associated with disorders such as autism spectrum, schizophrenia, depression, and addiction (Nestler et al. 2016). Cross-species comparisons have also revealed CLOCK as a hub unique to transcription networks in the human frontal lobe that are related to brain development, human language emergence, and neuropsychiatric disease. Furthermore, in cell-based studies, CLOCK was found to coordinate neuronal migration, consistent with a role in early development, transcription network complexity, and diverse aging pathologies (Babbitt et al. 2010; Konopka et al. 2012; Fontenot et al. 2017). Human brain development and transcriptional networks are also tightly coupled with splicing, which generates an additional level of neuronal diversity (Fogel et al. 2012). Splicing also exhibits robust rhythmic variation in fly brains (Wang et al. 2018), indicating that regional and temporal regulation may involve not only TF collaboration but also cell type-specific splicing events.

In mammalian systems, light and daily activity promote transcription as well as modifications to DNA and histone complexes within neurons. Discovery of immediately early genes (IEGs) within neurons (Greenberg and Ziff 1984) provided original insight into the link between environmental signals and neuronal transcription. Studies have also linked circadian behavioral entrainment to the release of neurotransmitters, such as serotonin, dopamine, and somatostatin, that ultimately can induce transcriptional reprogramming in somatostatin-expressing cells (Edgar et al. 1997; Dulcis et al. 2013). Development of long-term memory in the hippocampus is also tightly coupled to activity-induced expression of the core circadian repressor PER1, and overexpression of PER1 restores age-related memory impairment in mice (Kwapis et al. 2018). Activity-dependent transcription unique to vasoactive intestinal peptide (VIP)-expressing neurons has also been demonstrated to affect synaptic input into these cells through a light-dependent mechanism (Mardinly et al. 2016), raising the possibility that distinct cell types within the central pacemaker neurons may likewise exhibit unique transcriptional regulation in response to altered day length or with shifts in light exposure.

Translation of processed mRNAs represents an important step in the circadian control of protein accumulation (Lim et al. 2011). Circadian regulation of translation initiation occurs through multiple molecular events (for detailed reviews, see Lim and Allada 2013; Green 2018). The mTOR effector kinase ribosomal S6 protein kinase 1 (S6K1) phosphorylates BMAL1 in the cytoplasm, which leads to subsequent association of BMAL1 with the translational machinery (Lipton et al. 2015). Investigation of rhythmic ribosome-mRNA assembly in the liver has also revealed temporal enrichment of genes associated with ribosome biogenesis, including translation initiation factors (eIF4E and eIF4E-BP) that are targeted by canonical mTORC1 signaling (Jouffe et al. 2013). Similarly, RNA sequencing of hypothalamic energy-sensing neurons also reveals morning versus evening enrichment of genes encoding factors involved in ribosome biogenesis, which is unique to the ribosome-bound versus whole-cell mRNA level, indicating that molecular profiling at the translational level may provide insight into the rhythmic control of activity of neurons involved in hunger and appetitive drive (Cedernaes et al. 2019). Ablation of the mTOR translational regulator 4E-BP1 leads to alterations in entrainment of mice to light (Cao et al. 2013), an observation that may be explained through direct effects on VIP neuron signaling and/or synaptic input (Costa-Mattioli et al. 2009). In addition, translation elongation factors and use of upstream open mRNA reading frames have also been implicated in the regulation of rhythmic translation (Janich et al. 2015; Caster et al. 2016).

\section{Neuroanatomical and functional hierarchy of the central circadian system}

Research over the last decades has established a hierarchical model for circadian organization in which the central pacemaker clock within the suprachiasmatic nucleus (SCN) acts to control and maintain robust rhythms in physiology and behavior through synchronization of cellautonomous extra-SCN and peripheral tissue clocks (Fig. 2; Herzog et al. 1998; Morris et al. 1998; Saini et al. 2013). Early lesioning studies showed that ablation of the SCN at the base of the hypothalamus resulted in loss of rhythmicity in drinking behavior and locomotor activity, establishing the SCN as the central master pacemaker (Moore and Eichler 1972; Stephan and Zucker 1972). Subsequent studies using xenografts demonstrated that the SCN from a donor animal can determine circadian behavioral rhythms in a host animal and that such xenografts can maintain at least some of these rhythms through diffusible neurochemical signals as opposed to direct neuroanatomical connections, even in mammals (Silver et al. 1996). Such diffusible signals are even able to entrain circadian rhythms in cultured astrocytes (Prolo et al. 2005). Case studies, histopathological studies, and functional imaging studies (with magnetic resonance imaging [MRI]) all point to an identical role of the SCN in light entrainment and regulation of circadian rhythms in humans /Cohen and Albers 1991; Schmidt et al. 2009; Vimal et al. 2009; Wang et al. 2015; McGlashan et al. 2018).

Notwithstanding the dominant role of the SCN, it has become clear that both peripheral tissue clocks and extra-SCN clocks within the CNS are involved in maintaining organismal fitness. Indeed, brain regions outside of the SCN also exhibit circadian cell-autonomous cycles in isolation, which in some cases have different phases and a substantial number of cycling genes, such as the arcuate nucleus of the hypothalamus (Abe et al. 2002; Mure et al. 2018), but the circadian interplay across these 


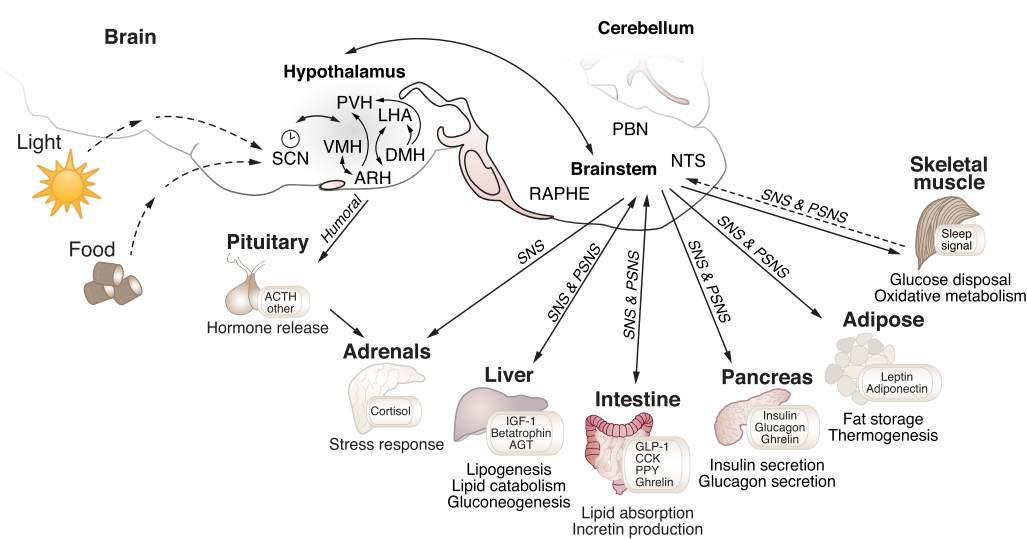

regulates release of cortisol, an important signal of entrainment for peripheral oscillators (Balsalobre et al. 2000). Multiple hypothalamic outputs are conveyed through the brain stem, such as the raphe, parabrachial (PBN), and tractus solitarius (NTS) nuclei, onto sympathetic nervous system (SNS) or parasympathetic nervous system (PSNS) tracts that regulate peripheral tissue rhythms, such as through sympathetic signals to brown adipose tissue to regulate rhythms in thermogenesis (Orozco-Solis et al. 2016). Feeding and drinking behavior is regulated through an interplay with peripheral tissues, such as the gastrointestinal tract (which produces signals that act on the brain, including glucagon-like peptide-1 [GLP-1], cholecystokinin [CCK], pancreatic polypeptide [PPY], and ghrelin). Highlighting the interplay with peripheral metabolism, several peripheral tissue-derived signals also regulate the central circadian system, including ghrelin, leptin, and fibroblast growth factor-21 (FGF-21) (Bookout et al. 2013; Kettner et al. 2015; Cedernaes et al. 2019), by acting on the SCN or extraSCN oscillators such as AgRP-expressing cells within the hypothalamus, although the identity of other such putative signals remains to be established (Ehlen et al. 2017).

critical brain regions and neuronal and potential glial subpopulations remains unknown.

\section{Entrainment of central pacemaker rhythms through cAMP and immediate early gene signaling}

The SCN receives its light input through monosynaptic projections from intrinsically photosensitive retinal ganglion cells (ipRGCs) that express melanopsin (Gooley et al. 2001; Hattar et al. 2006; Güler et al. 2008) and project through the retinohypothalamic tract (RHT) to the ventral "core" portion of the SCN. This region contains the largest proportion of neurons expressing the neuropeptide VIP within the SCN. Light activates the RHT to promote the release of glutamate, which acts on N-methyl-D-aspartate (NMDA) receptors (Ding et al. 1994), and the pituitary adenylate cyclase-activating polypeptide (PACAP), which targets PACAP and VIP receptors in the SCN. Glutamate and PACAP lead to increased firing of core VIP-expressing SCN cells and phase shift the SCN circadian clock when light exposure occurs during either the beginning or end of the dark period (Hannibal et al. 1997).

VIP neuronal activity and release are the most important signals to maintain proper circadian rhythms within the SCN (Maywood et al. 2011). Indeed, mice genetically deficient for the VIP and PACAP receptor VPAC2 (Vipr2 ${ }^{-/}$mice) lack normal circadian rest/activity rhythms as well as light-induced activation of immediate early and clock genes in the SCN (Harmar et al. 2002). Within the SCN, VIP and VIP receptor mutant mice exhibit about half as many rhythmic neurons as wild-type mice (Aton et al. 2005). These observations support a hierarchical model in which SCN activity and SCN cell en- semble synchronicity are predominantly controlled by VIP signaling (Aton et al. 2005; Maywood et al. 2011).

The importance of VIP neurons in central pacemaker activity has also been demonstrated in studies involving administration of VIP or its antagonist (Cutler et al. 2003; Aton et al. 2005) and more recently by studies involving genetically targeted functional manipulations of these neurons in adult mice (Aton et al. 2005; Maywood et al. 2011; Jones et al. 2018). Human postmortem studies also suggest that VIP neurons within the SCN are critical for maintaining proper circadian rhythms, as the number of such neurons correlates with diurnal amplitude in locomotor activity in both healthy and Alzheimer disease patients (Wang et al. 2015).

VIP neurons set the circadian time and phase shift circadian rhythms by VIPergic and $\gamma$-aminobutyric acid (GABA)-ergic signaling to arginine vasopressin (AVP)-expressing cells within the shell of the SCN. Mice lacking Bmal1 within AVP neurons still exhibit behavioral circadian rhythms (albeit with a longer period and less robust SCN coupling), indicating that the molecular clock machinery is dispensable within AVP neurons (Mieda et al. 2015). In contrast, mice that lack Bmal1 within both VIP and AVP neurons become arrhythmic in constant darkness (DD). The latter was demonstrated by targeting Bmal1 ablation to neurons that express the neuropeptide neuromedin-S (NMS), which encompasses almost all VIP and AVP SCN neurons (Lee et al. 2015).

Evidence suggests that both inhibitory and excitatory GABAergic connections are present within the SCN and that at least some can switch polarity across the circadian cycle (Freedman et al. 1999). The functional heterogeneity introduced through the presence of intermixed excitatory GABA action within the SCN may enable light-induced 
phase advances and phase shifts to nonphotic stimuli (McNeill et al. 2018). More work is required to understand whether such excitation-inhibition switches influence SCN projections arising from either VIPergic or AVPergic cell types, but other circuits have also been described as having GABA-induced excitatory receptors, such as in AVP-expressing paraventricular hypothalamic ( $\mathrm{PVH})$ cells (Haam et al. 2012).

Notably, GABAergic output from SCN VIP neurons is not necessary to maintain circadian rhythms but appears to introduce jitter in clock oscillations to effectively oppose the synchronizing action of VIP signaling on SCN neurons, enabling light-induced phase shifts of circadian rhythms (Freeman et al. 2013). Whether circadian variations in excitatory/inhibitory and firing modalities also exist for neurotransmitters involved in energy-sensing circadian circuitry is also of interest given that neurotransmitter pathways may function at more proximate timescales compared with neuropeptidergic signaling (Krashes et al. 2013) and that neurotransmitters respond dynamically at the transcriptional level to changes in nutrient state across the sleep/wake cycle (Cedernaes et al. 2019).

Cell physiologic and transcriptional analyses have further defined how anatomically distinct cell groups within the pacemaker nuclei entrain the organism to variations in day length. VIP neurons respond to light through the activation of several convergent signaling pathways. For example, glutamate-induced VIP stimulation of NMDA and a-amino-3-hydroxy-5-methyl-4-isoxazolepropionic acid (AMPA) fast ionotropic neurotransmitter receptors results in calcium influx and subsequent activation of calcium/calmodulin-dependent protein kinase (CaMK), mitogen-activated protein kinase (MAPK), and protein kinase A (PKA) (Kornhauser et al. 1990; Jakubcakova et al. 2007).

During the subjective night, light induces phosphorylation and activation of cAMP response element (CRE)binding (CREB) protein (at $\mathrm{CREB}^{\mathrm{S} 133}$ and $\mathrm{CREB}^{\mathrm{S} 142}$ ), which then binds to CREs in the promoters of Per1 and Per2 as well as to cFos and other IEGs within the SCN (Gau et al. 2002), a molecular pathway that is critical for light-induced phase shifts in circadian behavior /Chen et al. 1999). PACAP also stimulates cellular cAMP/PKA signaling, resulting in CREB-induced activation of Period genes in retino-recipient SCN neurons, and, intriguingly, this signaling, but not glutamate-induced CREB signaling, can be modulated by melatonin (Hannibal et al. 1997; von Gall et al. 1998). PACAP itself seems to modulate the response of SCN cells to glutamate during the early night (Harrington et al. 1999; Michel et al. 2006). Interplay between glutamate and PACAP signals-and possibly also with melatonin-may thus explain how the circadian clock and behavior are phase-delayed or phase-advanced by light stimuli either early or late during the subjective night. Furthermore, key signaling molecules such as DEXRAS1 within SCN neurons may regulate how photic versus nonphotic stimuli are able to entrain SCN-driven circadian rhythms (Cheng et al. 2004). Finally, activation along the MAPK pathway involves phosphorylation of
ERK proteins in the SCN (Cheng et al. 2004). These proteins may in turn further modulate the cAMP response through CREB in the SCN as well as participate in phosphorylation of core molecular clock components BMAL1, CLOCK, CRY1, and CRY2 (Goldsmith and Bell-Pedersen 2013). An important question remains concerning whether phosphorylation of PER2 mediates changes in period length via direct inhibition of clock activators by chromatin binding, a question investigated in orthologs of these proteins in Drosophila (Nawathean and Rosbash 2004).

Variation in excitatory (glutamate and GABA), inhibitory (GABA), and modulatory (PACAP and melatonin) neurotransmitter/neuropeptide responses may mediate activity of the neuronal clock but also may be a downstream output of the clock through rhythmic variation in the transcription of signaling factors, such as has been observed recently through transcriptomic analyses within NPY/AgRP neurons. Here, IEGs exhibit greater expression in the subjective evening compared with morning, consistent with potential differences in activity of these cells across the day (Cedernaes et al. 2019). This could be reflective of circadian variation in excitatory or peptidergic input to these neurons across the sleep/wake cycle, similar to that described above for the SCN.

Suggesting that the circadian clock may gate the molecular response to such inputs, ablation of the cell-autonomous clock in NPY/AgRP neurons shifted the zenith of the transcriptional response to leptin from morning to evening (Cedernaes et al. 2019). Regions connected to the SCN, such as the dorsomedial hypothalamic (DMH) nuclei (Elmquist et al. 1998; Chou et al. 2003) also express leptin receptors and modulate AgRP neurons through direct projections (Garfield et al. 2016). Altogether, this could suggest that the timing of the appropriate leptin response in energy-sensing neurons depends on both the cell-autonomous clock within such neurons and nonautonomous rhythmic signaling mediated by SCN-derived projections.

Interplay between the circadian clock, sleep/wake state, and cellular redox homeostasis has also been shown to regulate neuronal excitability (Cao and Nitabach 2008; Flourakis et al. 2015; Kempf et al. 2019). In Drosophila, oscillations in resting membrane potential are driven by rhythmic CLOCK-dependent expression of NCA localization factor 1 (NLF-1), and in sleep-promoting dorsal fanshaped body (dFB) neurons, accumulation of mitochondrial reactive oxygen species during sleep loss slows the inactivation of a potassium channel to increase neuronal firing, thereby promoting sleep. Such mechanisms may be important not only in regulating sleep/wake and CNS pacemaker neuron synchrony but also in determining day versus night differences in output from SCN to metabolic and sleep-regulating regions (Tabuchi et al. 2018). One of the main features of the SCN is increased daytime light-induced neuronal firing regardless of whether a species is day- or night-active (Yan et al. 2018). Differences in circadian output could therefore involve differences in how circadian temporal codes from the SCN or 
interneurons are read by downstream neurons driving behavioral and physiological outputs.

\section{Neurotransmitter and peptidergic signals in circadian clock circuit communication with appetitive cells}

The SCN exhibits time-of-day-dependent light responsiveness, as light pulses applied during the first half of the subjective night (i.e., the active phase in nocturnal animals) cause phase delays, while light in the late evening causes phase advances. In humans and other diurnal species, light exposure during the early evening causes a delay in waking and sleep onset the following day. How such differential delay and advance signals are mediated remains an area of inquiry. One possible explanation for differing behavioral responses at different times of day may arise from rhythmic variation in postsynaptic signaling pathways across the light-dark cycle and/or different combinations of inhibitory/activating signals /glutamate, GABA, and PACAP) and/or timescales (transmitter vs. peptide) (Harrington et al. 1999; Michel et al. 2006; Freeman et al. 2013; Krashes et al. 2013).

Extra-SCN brain regions involved in appetite and peripheral metabolic regulation share signaling mechanisms with SCN cells. These mechanisms encompass ligands and receptors for neurotransmitters, such as glutamate, GABA, dopamine, dynorphin, and serotonin (Przewlocki et al. 1983; Heisler et al. 2006; Knight et al. 2012), as well as neuropeptides, such as leptin, galanin, ghrelin, and PACAP (Knight et al. 2012; Krashes et al. 2014; Andermann and Lowell 2017). Extra-SCN neuronal expression of these peptides and their receptors as well as their downstream signaling pathways have been found to be influenced by both nutrient state (Knight et al. 2012; Henry et al. 2015; Cedernaes et al. 2019) and time of day (Watts and Swanson 1989; Castañeda et al. 2004; Hampp et al. 2008; Cedernaes et al. 2019). Several reproductive hormones, such as estrogen and testosterone, also exhibit circadian rhythms, which are able to feed back to the CNS to alter circadian rhythms and behavior (Kriegsfeld and Silver 2006). Notably, all such feedback may not impinge on the SCN, as ablation of arcuate hypothalamic (ARH) kisspeptin neurons results in altered activity levels and temperature rhythms without affecting ex vivo SCN rhythms (Padilla et al. 2019). Many of these hormonal axes are known to be independently modulated by nutrient state (Olson et al. 1995; Samuels and Kramer 1996), suggesting that feeding/fasting cycles may interact with reproductive axes to influence circadian behavior and metabolism.

Some neuropeptides (e.g., Galanin and Neuromedin B mRNA) not only exhibit nutrient- and/or sleep/wake-dependent regulation at the transcriptional mRNA level but also are enriched among ribosome-bound mRNAs (Knight et al. 2012; Cedernaes et al. 2019). This suggests that energy-sensing neurons also exhibit sleep/wake regulation at the translational level. Central circadian metabolic networks and signals of nutrient state may thus act in concert across transcriptional and posttranscrip- tional levels to gate neuronal outputs underlying organismal physiology and behavior according to time of day.

Further refinement in identification of circadian and hunger neuron interactions may emerge from single-cell profiling and anatomically more refined cell type-specific profiling. For instance, along the anteroposterior axis of the PVH, individual cells exist that are either activated or inhibited by leptin (Ghamari-Langroudi et al. 2011). Similarly, subgroups of POMC cells within the ARH responded differentially to leptin and insulin (Williams et al. 2010). Furthermore, cells within the median eminence, in which the ARH resides, have been found to contain 50 transcriptionally unique neuronal populations, including subpopulations that inhibit PVH and express diverse peptides, including NPY/AgRP and somatostatin (Campbell et al. 2017). Intriguingly, these populations may not necessarily be static, given both developmental changes that can confound CRE-defined populations $(\mathrm{Pa}-$ dilla et al. 2010) and environmental factors such as seasonal changes in photoperiod (Dulcis et al. 2013). The latter has been investigated by exposing mice to shortday versus long-day photoperiods. Short-day exposure was found to increase dopamine (i.e., presynaptic) expression in the $\mathrm{PVH}$ of neurons that otherwise express somatostatin (SST) while also increasing corresponding postsynaptic dopamine receptor expression onto downstream neurons that express corticotrophin-releasing factor (Dulcis et al. 2013).

\section{Feeding as a signal of entrainment}

When food is available for only a limited time period each day, animals exhibit increased activity in anticipation of feeding even when this occurs out of phase with the light-dark cycle (termed food anticipatory activity [FAA]). The extent to which shifted timing of food availability impacts circadian behavior has been described to depend on nutrient state, as hypocaloric but not normocaloric feeding during the day in mice led to a significant phase advance (2-3 h) of locomotor activity rhythms, pineal melatonin, and mRNA levels of AVP in SCN sections (Mendoza et al. 2005). Similarly, simply reducing food intake and/or decreasing ambient temperature can increase daytime activity; these changes may thus represent an adaptive response, as increased activity during the warmer daytime would enable energy expenditure to be reduced when required (van der Vinne et al. 2014). Overexpression of the fasting-induced hormone fibroblast growth factor21 (FGF-21) — as well as feeding mice a ketogenic diet, which is a potent inducer of FGF-21 release-also increases daytime activity and advances the phase angle of entrainment (Bookout et al. 2013), suggesting a mechanism through which nutrient state can modulate the distribution of locomotor activity across the sleep/wake cycle.

Intriguingly, a greater discrepancy between the midpoint of sleep on weekdays versus weekend days has been correlated with body mass index (BMI), a phenomenon referred to as "social jet lag" (Roenneberg et al. 
2012). This suggests that misalignment of sleep/wake and feeding/fasting cycles increases the risk of obesity in humans. This could also indicate that metabolic homeostasis influences circadian phase of entrainment, in line with the observation that obesity in high-fat diet (HFD)-fed mice causes disruption of circadian rhythms (Kohsaka et al. 2007; Hatori et al. 2012) and as also indirectly supported by clinical studies of subjects with metabolic disease such as obesity and type 2 diabetes (Otway et al. 2011; Stenvers et al. 2019).

The contribution of specific neurons to FAA has remained controversial, as animals with SCN or DMH lesioning (or molecular clock ablation targeted to these regions) still exhibit FAA (Landry et al. 2007; Storch and Weitz 2009; Izumo et al. 2014). Nonetheless, molecular disruption of $\mathrm{G}$ protein-coupled receptor (GPCR) signaling in the SCN has also been shown to alter entrainment to both light and food, consistent with interactions and/or sensitivity of the SCN to food when circadian cues of light cannot supersede those from food (Bouchard-Cannon and Cheng 2012). VPAC2-null mice exhibit increased daytime feeding and a corresponding phase advance in their corticosterone and hepatic gene expression rhythms, with all of these parameters rapidly phase-advancing when mice are released into DD (Sheward et al. 2007). Even though these mice have a nonfunctional SCN and become arrhythmic in DD, they are able to entrain their food intake rhythms as well as peripheral hepatic expression rhythms to food restriction (Sheward et al. 2007).

Indeed, earlier studies had shown that entrainment of peripheral clocks can be dissociated from that dictated by the SCN to anticipate a shifted timing of nutrient availability. Thus, inverting food availability in wild-type rodents quickly shifts peripheral tissue clocks, occurring among the fastest in the liver (Damiola et al. 2000; Stokkan et al. 2001). Importantly, under such conditions, the clock gene rhythms within the SCN remain entrained to the light/dark cycle, suggesting that food timing does not impact the SCN rhythm. However, in the absence of light, the SCN-controlled behavioral rhythm can be driven by food availability. In DD, mice normally follow their endogenous circadian rhythm, which yields a period length that is shorter ( $23.75 \mathrm{~h}$ for C57BL6 mice) than the 24-h Earth day (being slightly longer in humans at 24.18 h) (Czeisler et al. 1999). This daily shift in the onset and offset of locomotor activity can be prevented by restricting food availability to a time-locked feeding window during the active period (Damiola et al. 2000). A similar role for food timing as a potential dominant Zeitgeber for behavior was demonstrated in hypothalamic circadian mutant mice in which the behavioral arrhythmicity that was observed in DD could be rescued by restricted feeding (Izumo et al. 2014).

Entrainment of behavior to restricted feeding, as described above, has been speculated to be driven by a clock gene-driven "food-entrainable oscillator" (FEO) in the CNS, specifically within the DMH (Fuller et al. 2008). Evidence suggests that the FEO may involve signaling to metabolic centers, given that melanocortin 3 receptor (MC3R) knockout mice exhibit reduced anticipatory ac- tivity and wake behavior prior to scheduled restricted food availability (Sutton et al. 2008). However, given that Bmal1 ablation driven by CamKIIa also targets hypothalamic nuclei such as the $\mathrm{DMH}, \mathrm{ARH}$, and ventromedial hypothalamic (VMH) regions, this suggests that entrainment to time-restricted feeding does require a cell-autonomous clock in these centers (Storch and Weitz 2009; Izumo et al. 2014).

\section{Circadian neurocircuitry regulating appetite, sleep, and energy homeostasis}

Emerging evidence from studies in both circuit mapping and gene targeting indicate that the central circadian system functions as an ensemble of oscillators across different brain regions. Anterograde tracing of output fibers from the SCN has revealed projections to a range of regions, such as the subparaventricular zone (SPvZ), median preoptic (MPO) nucleus, DMH nucleus, and PVH nucleus, that may be critical for synchronizing sleep/wake and metabolic processes (Watts and Swanson 1987; Abrahamson and Moore 2001; Saper et al. 2005).

$\mathrm{PVH}$ cells regulate pituitary secretion of hormones involved in metabolic and physiological rhythms, such as $\mathrm{CRH}$ for cortisol release, thyrotropin-releasing hormone (TRH), oxytocin, and AVP. Evidence also exists that the SCN projects close to PVH-specific CRH and AVP cells in humans (Dai et al. 1998). Notably, studies in mice have found that PVH cells also project to AgRP cells (Krashes et al. 2014) and may, as such, constitute a polysynaptic relay between the SCN and its regulation of hormonal and behavioral axes. While SCN control of the PVH has been established at a neuroanatomical level, the molecular identity of involved receptors and origin/recipient cell types across the sleep/wake cycle remains unknown, as is the case for most of such established or putative SCN projections.

The SCN projects to many hypothalamic sites that may indirectly impact sleep, including the DMH (which controls autonomic nervous system activity), the ventrolateral preoptic area (Deurveilher et al. 2002), and the zona incerta (Liu et al. 2017), the latter of which may coregulate sleep with the feeding/fasting state (Zhang and van den Pol 2017). The SCN also projects to the lateral hypothalamic area (LHA) (Horvath et al. 2012), which contains wake-promoting hypocretin (Hcrt; also called Orexin)-expressing neurons that are critical for proper regulation of sleep/wake state and transitions across sleep stages (Sakurai et al. 1998; Adamantidis et al. 2007). Sleep-active neurons that express melanin-concentrating hormone $(\mathrm{MCH})$ are also found within the LHA as well as GABAergic neurons. Both of these project through local connections to wake-promoting hypocretin/orexin neurons (Ferrari et al. 2018), which in turn also feed back to control activity of LHA MCH but not interspersed GABAergic neurons (Apergis-Schoute et al. 2015; Ferrari et al. 2018). As such, the LHA exemplifies how interspersed cells within the same region can have opposing physiological functions, similar to communication 
within arcuate nuclei between AgRP/NPY and POMC cells (Andermann and Lowell 2017) or between leptin-responsive cells within the PVH (Ghamari-Langroudi et al. 2011).

Additional regions receiving SCN projections, such as the SPvZ, DMH region, PVH region, and VMH region, contain leptin-activated or leptin receptor-expressing cells, raising the possibility that such cell types integrate energy-sensing and circadian signals. Furthermore, drinking behavior seems to be regulated through projections from AVP cells within the SCN to the hypothalamic organum vasculosum lamina terminalis (OVLT) to promote increased thirst drive prior to sleep onset (Gizowski et al. 2016). The MPO and the subfornical (SFO) regions are also involved in drinking behavior, the latter in relation to homeostatic regulation in response to ingested food and fluids (Zimmerman et al. 2016). The SFO region has been found to project to the SCN, altogether suggesting bidirectional modulation of drinking behavior that involves the SCN (Lind et al. 1982).

SCN projections to the DMH have been identified through both classical tracing and genetic circuit mapping to interconnect food intake and sleep/wake patterns (Watts and Swanson 1987; Chou et al. 2003). Leptin-responsive cells within the DMH regulate thermogenesis (Dodd et al. 2014), which may occur via anterograde projections to glutamatergic cells in the raphe nucleus in the brain stem (Machado et al. 2018), in turn stimulating thermogenic activity in brown adipose tissue (BAT). The $\mathrm{VMH}$ has also been shown to regulate thermogenesis in addition to activating the adrenergic nervous system counterregulatory response to hypoglycemia (Kang et al. 2006). Since SCN projections reach both the DMH and $\mathrm{VMH}$, there may be redundancy with respect to circadian control of energy balance and glucose homeostasis (Orozco-Solis et al. 2016; Machado et al. 2018).

The SCN may also regulate body temperature through projections to the MPO (Luo and Aston-Jones 2009), a region well recognized for its role in sensing organismal temperature (Tan et al. 2016). Intriguingly, although a key feature of the periodicity of circadian gene oscillations is temperature insensitivity, entrainment of the clock has been shown to involve induction of the heat shock factor 1 (Buhr et al. 2010; Saini et al. 2012). Torpor, a state of energy conservation induced by short days of winter, is also characterized by reduced locomotor activity and core body temperature (Geiser 2004). Core body temperature also exhibits circadian and sleep regulation, with lower body temperature during rapid eye movement (REM) sleep (Czeisler et al. 1980), a sleep stage that has been particularly tied to regulation by the central circadian system (Czeisler et al. 1980; Edgar et al. 1993). Intriguingly, REM sleep may also be influenced by ambient temperature (Gotic et al. 2016). Thermoregulation thus represents an intriguing feed-forward and feedback aspect of physiologic homeostasis that is tightly coupled to circadian and sleep/wake systems at the level of brain and peripheral tissues (Gotic et al. 2016).

In addition to hypothalamic regions involved in appetitive and glucoregulatory control, some SCN neurons also project indirectly to regions involved in reward, such as the ventral tegmental area (VTA) via the medial preoptic nucleus (Luo and Aston-Jones 2009). VTA neurons project to the striatum, a region involved in reward and reinforcement processing (Beier et al. 2015). Activity of VTA dopaminergic neurons is also modulated by LHA-Hcrt input, an excitatory pathway that has been found to increase VTA dopaminergic cell activity during the active but not rest phase in mice (Moorman and Aston-Jones 2010). In addition to providing functional feed-forward regulation of hypothalamic energy circuits, feedback signals from both reward and appetitive centers also have been identified within the SCN. For instance, a large proportion of SCN neurons express the type 1 dopamine receptor (DRD1). VTA input to DRD1 SCN neurons has been demonstrated to be involved in modulating circadian entrainment of activity cycles (Grippo et al. 2017), a further indication of the complex cross-talk across brain regions involved in sensing energy state versus controlling circadian behavior.

Input to the SCN also arises from hypothalamic and brain stem areas, including the $\mathrm{PVH}$ and the preoptic area (Pickard 1982; Yuan et al. 2018), although the functional relevance of most such bidirectional circuits remains largely unknown. Serotonergic input from the brain stem raphe nuclei is particularly dense to the SCN (Meyer-Bernstein and Morin 1996; Pickard and Rea 1997) and may be involved in modulating functions such as how light and locomotor activity rhythms convey entrainment signals to the SCN (Rea et al. 1994; Marchant et al. 1997). Notably, the intergeniculate leaflets (IGLs) also indirectly convey light information to the SCN that is modulated by serotonergic input: The RHT signals to the IGLs, which also receive input from the dorsal raphe neurons (Meyer-Bernstein and Morin 1996). IGL projections (the geniculohypothalamic tract [GHT]) to the SCN via GABA and NPY provide signals that may thus fine-tune SCN entrainment by light through integration with nonphotic entrainment signals (Dibner et al. 2010). Sleep-related regions such as the paraventricular thalamus (PVT) also project back to the SCN (Alamilla et al. 2015; Ren et al. 2018), indicating that bidirectional signaling may exist between systems regulating sleep/wake and circadian behavior. Finally, distinct subtypes of ipRGCs (that are Brn3b-positive) have also been demonstrated to convey the acute response-but not circadian entrainment-of sleep and body temperature to light exposure. These subtypes do not directly target the SCN (Rupp et al. 2019) and thus highlight an additional layer of complexity to consider when interrogating neural mechanisms that underlie light-mediated circadian behavior and physiology.

\section{Glia-dependent regulation of circadian rhythms and metabolism}

Neuronal nutrient and neurotransmitter levels are highly dependent on adjacent astrocyte glial cells (Ioannou et al. 2019). Astrocytes are involved in neurophysiology 
relevant to behaviors controlled by nutrient-sensing brain regions such as the hypothalamus. These mechanisms encompass metabolic activity as well as synaptic plasticity and nutrient sensing. For instance, leptin's action on feeding circuits involves signaling through astrocytes, as deletion of astrocytic leptin receptors altered synaptic input and postsynaptic currents onto both POMC and AgRP neurons (Kim et al. 2014). Given that leptin signaling exhibits circadian regulation at the level of the CNS, it will be important to investigate whether CNS circadian processes regulated by leptin also involve its action on astrocytes. Astrocytes within the SCN and cortex exhibit fluctuations in the rhythmic release of ATP (Womac et al. 2009), indicating that rhythmic metabolism may impact how these glial cells regulate rhythmic firing thresholds or activity patterns in neurons. Further support for this notion comes from Clock mutant mice and mice that lack the PAS domain of the PER2 protein, both of which exhibit decreased levels of the glutamate transporter EAAT1 that is involved in astrocytic shuttling of glutamate. Astrocytes from the Per2 mutant mice were indeed observed to have a reduced capacity for glutamate uptake, which is involved in regulation of extracellular glutamate levels following its release by neurons (Spanagel et al. 2005; Beaulé et al. 2009).

Recent studies have expanded our insight into how astrocytes within the SCN are involved in modulating circadian rhythms, partly through their interactions with neighboring SCN neurons. SCN astrocytes exhibit rhythms that are similar to those of adjacent VIP neurons in terms of period length and circadian amplitude (Tso et al. 2017), but their core clock machinery (as indicated by Cry1-luciferase) is delayed by $\sim 6.5 \mathrm{~h}$. Bmal1 ablation targeted to SCN astrocytes increased period length, as assessed by animal locomotor activity, suggesting that the molecular clock within SCN astrocytes regulates mammalian circadian behavior (Tso et al. 2017). Contemporaneous characterization of the astrocytic clock demonstrated that SCN astrocytes display broader $\left[\mathrm{Ca}^{2+}\right]$ rhythms that are antiphasic to neighboring neurons such that SCN astrocytes are active during the circadian night and suppress firing of SCN neurons via signaling through the glutamatergic receptor subtype NMDAR2C (Brancaccio et al. 2017). Furthermore, arrhythmic clock mutant mice (Cry1/Cry2 double-knockout mice) can regain their circadian behavioral rhythms when the core clock machinery is restored in not only neurons but also astrocytes. This suggests that the cellular clock machinery within at least the SCN exhibits functional redundancy in programming behavioral rhythms in animals (Brancaccio et al. 2019). Synaptic pruning, which occurs during sleep and has been linked to AgRP neuron activity within the AgRP neurocircuitry (Liu et al. 2012), also relies on both microglia and astrocytes (Chung et al. 2013), with evidence for a role of the microglial molecular clock in this process (Hayashi et al. 2013). Metabolic functions such as lactate shuttling are likely another pathway that may rely on molecular clock function in astrocytes, though this remains to be investigated.

\section{Metabolic flux and redox homeostasis in the CNS}

Wakefulness, which is accompanied by increased availability of nutrients, promotes energy use in neurons, thereby resulting in greater production of waste products that reflect cellular metabolism and redox state, such as amyloid $\beta$ and $\tau$ proteins (Bero et al. 2011; Macauley et al. 2015; Ioannou et al. 2019). SCN cells sense and regulate cellular excitability according to redox state (Wang et al. 2012), and widespread brain targeted clock gene ablation has demonstrated that the neuronal clock is required to maintain CNS redox homeostasis at both the neuronal and glial levels (Musiek et al. 2013). Notably, metabolite influx to and efflux of nutrients and potentially toxic metabolites and drugs (e.g., amyloid $\beta$ ) from the CNS through the blood-brain barrier (BBB) occurs through several mechanisms, some of which have been found to be dependent on sleep/wake state and circadian mechanisms and rely on glial cells (Cirrito et al. 2005; Abbott et al. 2006; Xie et al. 2013; Nakazato et al. 2017; Taoka et al. 2018; Zhang et al. 2018).

The BBB permeability is regulated by astrocytic interactions with endothelial cells (Abbott et al. 2006), as astrocytes control trans-BBB nutrient and fluid uptake into the CNS from the periphery through endocytosis and aquaporin water channel proteins (Haj-Yasein et al. 2011). In mice, Bmal1 ablation throughout the brain using Nestin-Cre (which is expressed in the pericytes that regulate $\mathrm{BBB}$ integrity) increases permeability of the $\mathrm{BBB}$ (Nakazato et al. 2017), possibly due to reduction in PDGFR $\beta$ expression. At present, the role of a functioning cell-autonomous clock remains to be determined in the context of BBB function and xenobiotic clearance in mammals. In Drosophila, the perineural glia communicate rhythmically with subperineural glia via gap junction proteins, which are regulated by the PG cell-autonomous clock (Zhang et al. 2018). This results in day-night differences in xenobiotic efflux but not influx to the CNS, creating a daytime efflux (Zhang et al. 2018). Although speculative (Palomares et al. 2015), firm evidence of how disrupted sleep and circadian rhythms can regulate BBB function and drug bioavailability in humans is currently lacking.

Our understanding of the regulation of redox state across the sleep/wake cycle has been expanded with the recent discovery of the sleep-dependent glymphatic system. This brain-specific lymph-like system regulates the efficiency of the clearance of metabolites and other waste products from the brain. Glymphatic metabolic efflux is at its greatest during natural or induced sleep and the diurnal rest period (Xie et al. 2013; Taoka et al. 2018) and is related to fluctuations in size of the interstitial space between CNS neurons and glia. Ablation of AQP4, the main aquaporin expressed by astrocytes, greatly diminishes glymphatic efflux (Iliff et al. 2012; Murlidharan et al. 2016). The glymphatic system is involved in flow and clearance of several metabolites such as amyloid $\beta$ and lactate that are linked to neuronal activity and occur at higher concentrations in the wake versus sleep state (Xie et al. 2013; Lundgaard et al. 2017). Given that the SCN provides 
output signals through diffusion that are sufficient to produce circadian behavioral rhythms (Silver et al. 1996; Maywood et al. 2011), dynamic circadian changes in the glymphatic system may be critically involved in regulating how various CNS regions synchronize their activity across the sleep/wake cycle, potentially mediated through the control of neuropeptide, ionic, or metabolite diffusion, such as adenosine. It can only be speculated what type of paracrine signals this may involve (e.g., neuropeptides, energy metabolites such as adenosine, or possibly even fluctuations in ion levels) (Ding et al. 2016). Such signals may be driven by phase-dependent metabolic and genomic states of neurons and astrocytes, which in turn are regulated by the cell-autonomous clock.

\section{Redox and energy modulation of circadian function}

In peripheral tissues, many metabolic pathways exhibit circadian regulation at the level of transcription, whereas emerging evidence has also shown that metabolites feed back to alter circadian function. The metabolite nicotinamide adenine dinucleotide $\left(\mathrm{NAD}^{+}\right)$exhibits robust oscillation, and its biosynthesis is under control of the clock. In turn, changes in $\mathrm{NAD}^{+}$levels feed back to affect the core circadian clock, while deficiency in $\mathrm{NAD}^{+}$has been found to impair mitochondrial function in circadian mutant mice (Ramsey et al. 2009; Peek et al. 2013). Even at the level of the brain, where the central pacemaker is resistant to modulation of its circadian rhythm by small variations in temperature and nutrients derived from food, manipulation of brain levels of the $\mathrm{NAD}^{+}$-sensitive protein SIRT1 has been found to impact behavioral circadian properties. Specifically, ablation of SIRT1 in the CNS using NestinCre prolonged the circadian period of mice and delayed re-entrainment in a jet lag protocol, similar to the slower entrainment seen in aged wild-type mice /Chang and Guarente 2013). Another set of factors that reflects cellular energy state is the AMP-dependent kinases (AMPKs), which sense cellular ATP levels. AMPK1 modulates CRY1 phosphorylation and thus its rhythmic degradation, a mechanism that has so far been investigated only in peripheral tissues (Lamia et al. 2009). As also described above, mTOR, another nutrient-sensing molecular pathway, can modulate the mammalian central pacemaker (Cao et al. 2013).A similar mechanism has been described in Drosophila (Zheng and Sehgal 2010).

A related question is whether signals of organismal energy state can signal back to the SCN to impact organismal circadian rhythms. Indeed, overexpression of FGF21 , which is elevated during fasting, or forebrain versus hindbrain targeted deletion of one of its receptor components, B-Klotho, revealed that FGF-21 acts centrally to lower insulin and that both overexpression of FGF-21 and its induction by a ketogenic diet reduce overall locomotor activity while increasing the proportion occurring during daytime (Bookout et al. 2013). Notably, FGF-21 impacted anabolic versus catabolic state in liver and adipose tissue through its action on the SCN (in the forebrain) versus hindbrain, suggesting feedback from SCN to tissues producing FGF-21 (Bookout et al. 2013). Neuropeptides such as ghrelin and leptin may also provide direct humoral modulation of central circadian rhythms by acting on SCN neurons (Prosser and Bergeron 2003; Yannielli et al. 2007; Yi et al. 2008; Inyushkin et al. 2009). More recently, evidence has emerged that the circadian clock in skeletal muscle may regulate sleep, as rescue of Bmal1 expression specifically in skeletal muscle restores non-REM (NREM) sleep seen in Bmal1 knockout mice, with no changes in locomotor activity rhythms (Ehlen et al. 2017). Altogether, this highlights the complex interplay that may exist between regulation of the circadian system, sleep/wake state, and peripheral energy metabolism (see also the section below).

\section{Brain clock disruption and peripheral tissue metabolism}

Lesioning or electrolytic ablation of the SCN was essential to initially establish how the circadian system regulates peripheral metabolism. Such lesioning resulted in peripheral clock desynchrony and altered peripheral glucose levels (Akhtar et al. 2002; Guo et al. 2005; Saini et al. 2013). This line of work also indicated that the SCN drives hepatic transcriptional cycles through the rhythmic hypothalamic-pituitary-adrenal (HPA) axis and subsequent hepatic glucocorticoid action (Strubbe et al. 1987; Chun et al. 1998; la Fleur et al. 2000; Reddy et al. 2007; Coomans et al. 2013). A caveat of lesioning, however, is the difficulty of achieving cell type specificity and the inability to target specific molecular cell-autonomous mechanisms.

Genetic evidence for a role of the cell-autonomous circadian clock in whole-organism glucose, lipid, adipokine, and energetic homeostasis was later provided by multitissue models that disrupt the molecular clock in both brain and all peripheral tissues (Turek et al. 2005). Subsequent conditional gene targeting studies using CRE recombinase to drive tissue-specific ablation revealed an essential role for clock genes in metabolism even in adult life (Lamia et al. 2008; Marcheva et al. 2010; Perelis et al. 2015; Bass and Lazar 2016). Ablation of clocks within the liver, an "anabolic tissue," leads to fasting-induced hypoglycemia, hypoketosis, and impaired mitochondrial fatty acid oxidation. In contrast, ablation of clock function in the pancreas causes impaired postprandial metabolism, characterized by hypoinsulinemia and hyperglycemia in ad lib-fed animals. The opposing actions of clocks within different tissue types highlights the need to systematically control for not only nutrient state (fasted vs. fed) but also time of day (morning vs. evening) when analyzing the effects of individual cellular clocks on whole-body homeostasis, such as those operating across brain regions (Abe et al. 2002).

In the brain, ablation of core clock genes has been achieved in neurons comprising or sparing the SCN or in brain regions involved in energy metabolism, such as specific extra-SCN hypothalamic nuclei (Cedernaes et al. 2019) and astrocytes (Musiek et al. 2013). Genetic 
studies have established that the positive and negative elements of the core clock machinery are required for the SCN to generate rhythms of wheel-running activity in DD, in which light can no longer function as a timed cue (i.e., a "Zeitgeber"). For instance, ablation of Bmal1 broadly across the forebrain, including $>90 \%$ of the SCN (using CRE driven by the Camk2a promoter), disrupted overall behavioral rhythms as well as ex vivo rhythms in SCN organotypic slices (Izumo et al. 2014). Conversely, gain-of-function studies show that rescue of clock expression in the SCN is sufficient to recover rhythmic locomotor activity (McDearmon et al. 2006; Hughes et al. 2012). Notably, even in animals lacking core clock components during development, chemogenetic restoration of the clock in the SCN only during adulthood is able to restore circadian behavior, demonstrating that absence of the TTFLs does not impair development of the rhythm-generating molecular machinery of the SCN (Maywood et al. 2018). Collectively, clock gene expression in the SCN is both necessary and sufficient for mammalian locomotor activity rhythms.

Recent work also indicates that the hypothalamic clock network controls hepatic glucose metabolism through vagal signaling (Cedernaes et al. 2019). Similarly, targeted ablation of the hepatic clock as well as genetic restoration of central clock gene expression in animals that are otherwise deficient for the functional core clock machinery have revealed that a proportion of hepatic transcriptional rhythms responds primarily to central, and presumably SCN-derived, cues (Akhtar et al. 2002; Kornmann et al. 2007; Hughes et al. 2012). Evidence also suggests that hepatic transcriptional rhythms are highly sensitive to timing of food intake (Damiola et al. 2000; Greenwell et al. 2019), which implies that, under conditions of circadian misalignment (e.g., in shift work), metabolic defects may arise from the misalignment of hepatic cellautonomous, food-driven, and SCN-driven oscillations in liver cells. Furthermore, the SCN regulates the release of melatonin. Since melatonin receptors are expressed in pancreatic $\beta$ cells, it has been proposed that melatonin may mediate glucose homeostasis through direct control of insulin secretion (Cipolla-Neto et al. 2014) in $\beta$ cells (Tuomi et al. 2016).

Several central oscillators outside the SCN have been investigated for their role in maintaining central and peripheral metabolic rhythms (Orozco-Solis et al. 2015, 2016; Cedernaes et al. 2019), and these studies have also begun to uncover molecular processes that underlie circadian regulation of such oscillators (Fig. 3). For instance, AgRP-specific ablation of the molecular clock increases reductive metabolism during the light period while also increasing daytime hepatic glucose production, similar to the role of fly neurons expressing the NPY ortholog NPF (Erion et al. 2016). This may be driven by abrogation of rhythm neuropeptide secretion or in disrupted posttranscriptional rhythms in the expression of proteins critical for mitochondrial function /Cedernaes et al. 2019), which has been found to be essential for AgRP neurons to properly promote feeding (Dietrich et al. 2013).

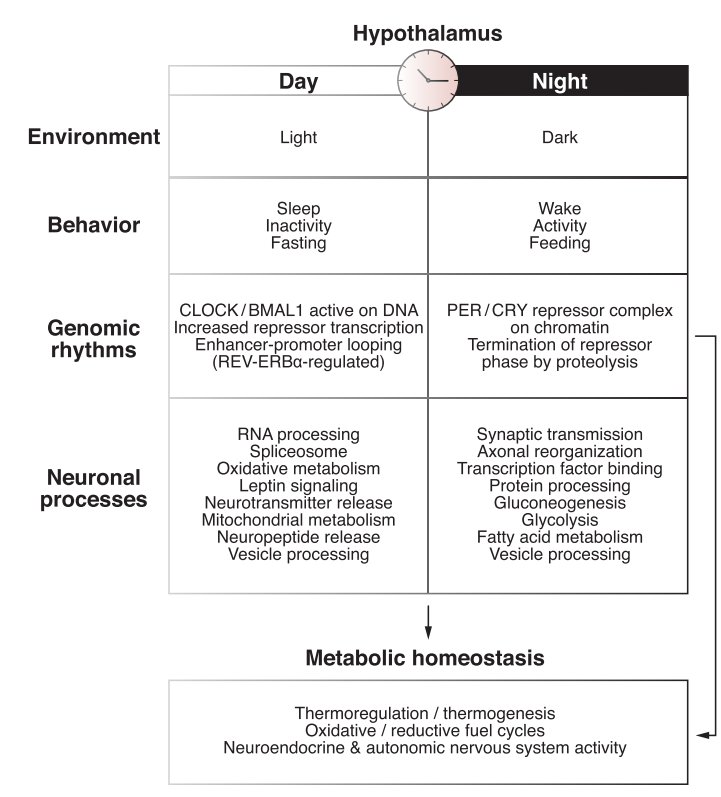

Figure 3. Neuronal and metabolic processes regulated by the hypothalamic clock. Light signals during the day promote sleep/quiescence and fasting in nocturnal organisms (but wakefulness and feeding in diurnal species such as humans). However, the molecular machinery between nocturnal and diurnal animals is largely maintained, and opposite behavioral rhythms are instead thought to be encoded by different central output pathways. During the day, clock activator elements CLOCK/BMAL1 are bound to DNA, mediating transcription of PER and CRY repressor elements. Emerging studies have begun to uncover how rhythms in neuronal transcription and posttranscriptional events contribute to regulation of behavioral and physiologic rhythms. Transcriptional profiling has demonstrated that leptin signals and mitochondrial oxidative metabolism seem to be active during the daytime (inactive behavioral period), whereas anabolic processes are active during the nighttime period (active behavioral period) (Panda et al. 2002; Cedernaes et al. 2019). Further analyses will be necessary to understand whether there are differences across brain regions within these neuronal processes, which in turn can be tied to region-specific or cell type-specific differences in control of appetite and energetic rhythms. Furthermore, a gap remains in understanding how rhythms are regulated at the epigenetic level and whether this represents a mechanism by which disruption of the central circadian system can be involved in long-term adverse consequences of circadian misalignment, as occurs in chronic shift work.

Energy expenditure is driven by several components, including muscle activity, muscle shivering, and glucose and lipid oxidation in BAT. Several of these functions are regulated at the level of the CNS by neuronal populations distributed across specific hypothalamic nuclei, such as the DMH, the VMH, the ARH, or the PVH, although the full neurogenetic identity and signaling mechanisms of each of these sites still remain to be determined. Deletion of Bmal1 targeted to the VMH increased energy expenditure and body temperature via increased BAT activity during the active phase and reduced body weight (Orozco-Solis et al. 2016). This effect seemed to be independent of altered activity of the cell-autonomous clock 
in BAT or the SCN, as core clock gene expression was disrupted only in the $\mathrm{VMH}$. In response to $\mathrm{VMH}$-specific Bmal1 ablation, increased expression levels of thermogenic, mitochondrial, and adrenergic activity genes (e.g., Ucp1, Adrb3, and Nrf1) were observed in BAT, and increased BAT activity was dependent on increased adrenergic activity. Whereas the independent role of the clock in the aforementioned extra-SCN sites has been explored, little is known currently about how the molecular clock within these regions is integrated with-or dependent on-rhythmic output from the SCN.

\section{Overlapping genetics of sleep and circadian rhythms?}

A major advantage of autonomous clocks in unicellular organisms is the coordination of photosynthesis with DNA photolyase activity (Thompson and Sancar 2002). Even in nonphotosynthetic cells, separation of reductive and oxidative pathways may provide protection from genotoxic damage (Rutter et al. 2002) and provides a conceptual framework to consider the teleology of circadian processes. At the behavioral level, the alternating stages of energy storage and utilization correspond with a daily quiescent period of immobility and reduced neuronal responsiveness that we refer to as sleep and which may have arisen early in the metazoan lineage, even before the CNS arose (Nath et al. 2017). Modern genetic tools such as opto- and chemo-genetics have widened our understanding of the neuronal brain regions that control sleep/wake states, including what specific neurotransmitters (such as orexin/hypocretin) are involved in this central regulation (Adamantidis et al. 2007). However, even though sleep occupies roughly a third of human life span, whether epigenetic and genetic changes may occur within specific neuronal cell types or networks in response to sleep per se is still in its infancy (Cirelli et al. 2004; Yelin-Bekerman et al. 2015; Chung et al. 2017). This lack of knowledge likely stems from multiple challenges, such as dissociating the effects of sleep restriction from those caused by the stress induced with sleep restriction methods in animals, and brain-specific genetically targeted analyses required to understand the molecular programs that neurons initiate during sleep have been lacking. Studies in flies and mice, however, suggest that sleep maintains metabolic homeostasis by promoting repair processes and protein synthesis within the CNS (Cirelli et al. 2004; Xie et al. 2013; Li et al. 2017). Conversely, sleep disruption results in metabolic stress (Zhang et al. 2014a), which may be one key mechanism through which disruption of sleep and circadian rhythms promotes the accumulation of neurotoxic substances within the CNS and neurodegenerative diseases in humans, rodents, and flies (Cedernaes et al. 2017).

Periods of sleep typically overlap with periods of fasting, especially in humans. Intriguingly, recent evidence has linked brain regions involved in regulation of sleep/wake cycles with the same neuronal populations that also regulate fasting/feeding. Specifically, orexigenic AgRP neurons within the arcuate nucleus have been found to promote wakefulness (Goldstein et al. 2018), while activating the reciprocal (anorexigenic) POMC neurons promoted sleep. Presently, it is unknown to what extent the local clock in these neurons modulates sleep/wake states and whether they interact with homeostatic sleep regulation. Given that these neurons exhibit clock gene modulation in response to shifting organismal energy state (exerted by fasting), it can be hypothesized that these neurons also modulate sleep through cell-autonomous clock regulation. Furthermore, studies in ob and $\mathrm{db}$ mice indicate that alterations in leptin signaling modulate sleep, suggesting that leptin signaling may play a key role in sleepor wake-promoting cell types (Laposky et al. 2006). The local clock may also exert sleep/wake control by modulatory input from, e.g., DMH and PVH, two regions known to project inhibitory and excitatory projections, respectively, to AgRP neurons and that in turn are modulated by the SCN (Chou et al. 2003; Krashes et al. 2014; Garfield et al. 2016).

In the widely accepted two-process model, sleep is modulated by circadian as well as homeostatic factors, characterized by the accrual of sleep drive with wakefulness. Gene variants have been discovered that modulate the circadian timing of sleep (Hu et al. 2016; Jones et al. 2016), homeostatic sleep regulation (e.g., Dec2/Bhlhe41 and Homer1a) (Maret et al. 2007; Pellegrino et al. 2014; Hirano et al. 2018), sleep duration (e.g., the protein kinase Sik3) (Funato et al. 2016), and properties of particular sleep stages in mammals (e.g., NALCN) (Funato et al. 2016). While evidence suggests that some of these genes, such as Sik3, have nonoverlapping effects on sleep or circadian systems, there are also variants of genes that not only regulate circadian rhythms (e.g., PER3) but also can modulate sleep (Viola et al. 2007). Hinting at how this may disclose neural circuitry that converges between sleep and timing systems, ablation of clock genes (e.g., in CLOCK mutant mice) (Naylor et al. 2000) or circadian-associated genes such as Vip also alters sleep duration or structure (Naylor et al. 2000; Wisor et al. 2002; Laposky et al. 2005; Hu et al. 2011; Zhou et al. 2014). However, in many such studies conducted to date, the genetic targeting has been unspecific with regard to the involved cell types and timing of the deletion (to exclude developmental effects). This has precluded conclusions as to what brain regions those genetic interventions target as well as whether interactions with peripheral tissues modulate the effects (Ehlen et al. 2017). Thus, further studies will be needed in which sleep is monitored in animals with cell type-specific modulation of clock gene function, ideally in settings in which cell activity can be turned on and off within circadian timeframes.

\section{Summary and questions}

Toward the end of his life, the late geneticist Sydney Brenner (Syd 1997; Venkatesh et al. 1997) often remarked that his major interest in biology had turned toward the hypothalamus because of its place as the seat of motivational behavior. In addition to its centrality in appetite regulation, Brenner (Bass and Takahashi 2011) acknowledged 
the role of the hypothalamus as central to the circadian system, which he characterized as guiding "things that you do only once each day." An organizing principle of hypothalamic functions derives from the concept of homeostasis, formulated by Claude Bernard (Cooper 2008) in the mid 19th century; i.e., the ability to maintain constancy in the internal milieu despite changes in the external environment. Consistent with Bernard's viewpoint (Saper and Lowell 2014), the hypothalamus plays a key role in maintaining body temperature necessary for survival and metabolic reactions while also coordinating growth and reproduction according to energy sufficiency. As discussed above, our understanding of the molecular mechanisms of hypothalamic-driven behavior emerged with the discovery of genes encoding the molecular clock, which provided a mechanistic entry point to merge molecular, pharmacological, and anatomical approaches toward understanding how the hypothalamus provides input into energy regulatory pathways. While the key phenotyping for circadian genetic studies were behavioral, molecular analyses of the circadian clock have centered primarily on clock function in peripheral tissues, especially liver. A recurring finding has been the reciprocal relationship between metabolism and the clock, with major metabolic pathways overrepresented as rhythmic circadian factors across most tissues and evidence that metabolites and oxygen feed back to regulate the core clock. However, despite advances in the field of circadian molecular biology, major questions remain in our understanding of intrinsic clock mechanisms at the level of individual neurons, glial cells, and circuits that manifest at the level of behavior and physiology.

Do circadian epigenetic mechanisms underlie rhythmic activity within energy-sensing neurons? The circadian clock is interlinked with epigenetic rhythms involved in chromatin modification in addition to RNA processing and translation. While core clock TFs rhythmically bind DNA in the liver, which also exhibits rhythmic chromatin remodeling (Koike et al. 2012), the extent to which this occurs in energy-sensing neurons and whether it drives oscillations in neuronal output remain unknown. Rhythmic epigenetic modifications in neurons may also be involved in modulating the ability of neurons to switch functional or rhythmic properties in response to stimuli such as light (Crosio et al. 2000; Dulcis and Spitzer 2008; Dulcis et al. 2013), macronutrients, or organismal energy state (Kohno et al. 2014). Epigenetic mechanisms can also be presumed to be involved in generating circadian oscillations in energy-sensing neurons, neurotransmitter and peptidergic release and/or response, or modulating the threshold for integrating input into acute and more long-term circadian firing patterns (Tabuchi et al. 2018) that may be involved in driving downstream neuronal circuitry. Conversely, epigenetic pathways are coupled to metabolism (Alenghat et al. 2008; Perelis et al. 2015), and changes across the sleep/wake-fasting/feeding cycle may affect neuronal activity through feedback from either changes in mitochondrial respiration or nucleotide turnover affecting methylation and acetylation reactions important in chromatin regulation.
To what extent is there cellular heterogeneity for functional metabolic output of the SCN? Whereas studies have begun to delineate how central oscillators regulate metabolism and feeding behavior (Orozco-Solis et al. 2015, 2016; Cedernaes et al. 2019), this so far has not considered potential subregional cellular diversity. In the SCN, studies have defined subregions based on expression of protein markers such as VIP, AVP, DRD1, cholecystokinin (CCK), gastrin-releasing peptide (GRP), and NMS, some of which exhibit partial overlap (Lee et al. 2015). Some of these SCN cell types have been functionally probed (Tso et al. 2017; Jones et al. 2018), but the extent to which these cells may be involved in regulating rhythmic feeding and metabolism and whether such populations also exhibit cellular heterogeneity in terms of function and their projection (efferent) or input (afferent) targets remain unanswered. Another outstanding question is whether these cells exhibit heterogeneity in terms of their sensitivity to being modulated by changes in environment as well as organismal energy state, such as HFD feeding, obesity, or nonthermoneutral temperatures. Single-cell sequencing provides an avenue to address such questions, yet this requires attention to exon-level analyses that is often missing with limiting single-end sequencing, given the important role for splice variants in determining neuronal function.

Does rhythmic core pacemaker activity functionally impact organismal energy balance? At its core, the molecular clock is driven by a transcription feedback loop, and the fundamental mechanisms of rhythmic physiology can be understood through analysis of transcription. Although elegant circuit-level mapping has provided insight into first-order neurons important in energy balance within hypothalamus (namely, the AgRP/NPY- and POMCexpressing cells within the arcuate nucleus) (Andermann and Lowell 2017), how the response to hormones varies across the day requires understanding of both circuit-level and cell-autonomous input from the circadian clock. Mounting evidence suggests that feeding at different phases of the light-dark/sleep-wake cycle exerts different effects on body weight and metabolic homeostasis, and emerging clinical studies indicate that these phenomena also translate to humans (Rothschild et al. 2014; Moro et al. 2016; Sutton et al. 2018). However, little is known concerning how time of day affects response to feeding within neuronal regulatory circuits. Specifically, the cell and molecular pathways that program time-of-day variation in sympathetic and parasympathetic tone remain incompletely understood. Does feeding at the "incorrect" time of the light-dark cycle promote diet-induced obesity through misalignment of central circadian-appetitive circuit communication and activity? Furthermore, does obesity alter rhythmic regulation of autonomic tone at the level of the hypothalamus and thereby reduce energy expenditure in response to overnutrition? The tools are now in hand to dissect the functional input of circadian neurons into appetitive cell types and interrogate the cell and molecular pathways that interconnect temporal and energy regulatory pathways important in long-term energy balance and metabolism. 
In summary, as Bernard predicted and Brenner appreciated (Syd 1997; Venkatesh et al. 1997; Bass and Takahashi 2011), the hypothalamus encompasses integrated systems to align environmental signals with homeostatic physiology and motivational behavior. Understanding how rhythmic transcription within individual neurons encodes activity within hypothalamic circuits as well as interlinked brain stem circuits and the response of these pathways to changes in environmental nutrients, light, and temperature holds the promise to provide insight into the relationship between cell- and circuit-level control of body weight and for determining the mechanism underlying memory of past weight gain or weight loss.

\section{Acknowledgments}

We thank Biliana Marcheva for illustrations, Kathryn Moynihan Ramsey for help with the manuscript, and Ravi Alada, Raj Awatramani, Talia Lerner, and Jim Surmeier for helpful discussions. This research was supported by National Institute of Diabetes and Digestive and Kidney Diseases (NIDDK) grants R01DK090625, R01DK113011, and R01DK100814; National Institute on Aging grant P01AG011412; Chicago Biomedical Consortium S-007; and University of Chicago Diabetes Research and Training Center grant P60DK020595 (to J.B.). J.C. was supported by the Swedish Society for Medical Research and the Swedish Brain Research Foundation. N.W. was supported by the T32 GM008061 training grant.

\section{References}

Abbott NJ, Rönnbäck L, Hansson E. 2006. Astrocyte-endothelial interactions at the blood-brain barrier. Nat Rev Neurosci 7: 41-53. doi:10.1038/nrn1824

Abe M, Herzog ED, Yamazaki S, Straume M, Tei H, Sakaki Y, Menaker M, Block GD. 2002. Circadian rhythms in isolated brain regions. I Neurosci 22: 350-356. doi:10.1523/JNEURO SCI.22-01-00350.2002

Abrahamson EE, Moore RY. 2001. Suprachiasmatic nucleus in the mouse: retinal innervation, intrinsic organization and efferent projections. Brain Res 916: 172-191. doi:10.1016/ S0006-8993(01)02890-6

Adamantidis AR, Zhang F, Aravanis AM, Deisseroth K, de Lecea L. 2007. Neural substrates of awakening probed with optogenetic control of hypocretin neurons. Nature 450: 420-424. doi:10.1038/nature06310

Akhtar RA, Reddy AB, Maywood ES, Clayton JD, King VM, Smith AG, Gant TW, Hastings MH, Kyriacou CP. 2002. Circadian cycling of the mouse liver transcriptome, as revealed by cDNA microarray, is driven by the suprachiasmatic nucleus. Curr Biol 12: 540-550. doi:10.1016/S0960-9822(02)00759-5

Alamilla J, Granados-Fuentes D, Aguilar-Roblero R. 2015. The anterior paraventricular thalamus modulates neuronal excitability in the suprachiasmatic nuclei of the rat. Eur J Neurosci 42: 2833-2842. doi:10.1111/ejn.13088

Alenghat T, Meyers K, Mullican SE, Leitner K, Adeniji-Adele A, Avila J, Bućan M, Ahima RS, Kaestner KH, Lazar MA. 2008. Nuclear receptor corepressor and histone deacetylase 3 govern circadian metabolic physiology. Nature 456: 997-1000. doi:10 $.1038 /$ nature 07541
Andermann ML, Lowell BB. 2017. Toward a wiring diagram understanding of appetite control. Neuron 95: 757-778. doi:10 .1016/j.neuron.2017.06.014

Apergis-Schoute J, Iordanidou P, Faure C, Jego S, Schone C, AittaAho T, Adamantidis A, Burdakov D. 2015. Optogenetic evidence for inhibitory signaling from orexin to $\mathrm{MCH}$ neurons via local microcircuits. I Neurosci 35: 5435-5441. doi:10 .1523/JNEUROSCI.5269-14.2015

Aryal RP, Kwak PB, Tamayo AG, Gebert M, Chiu P-L, Walz T, Weitz CJ. 2017. Macromolecular assemblies of the mammalian circadian clock. Mol Cell 67: 770-782.e6. doi:10.1016/j .molcel.2017.07.017

Aton SJ, Colwell CS, Harmar AJ, Waschek J, Herzog ED. 2005. Vasoactive intestinal polypeptide mediates circadian rhythmicity and synchrony in mammalian clock neurons. Nat Neurosci 8: 476-483. doi:10.1038/nn1419

Babbitt CC, Fedrigo O, Pfefferle AD, Boyle AP, Horvath JE, Furey TS, Wray GA. 2010. Both noncoding and protein-coding RNAs contribute to gene expression evolution in the primate brain. Genome Biol Evol 2: 67-79. doi:10.1093/gbe/evq002

Balsalobre A, Brown SA, Marcacci L, Tronche F, Kellendonk C, Reichardt HM, Schutz G, Schibler U. 2000. Resetting of circadian time in peripheral tissues by glucocorticoid signaling. Science 289: 2344-2347. doi:10.1126/science.289.5488.2344

Bass J, Lazar MA. 2016. Circadian time signatures of fitness and disease. Science 354: 994-999. doi:10.1126/science.aah4965

Bass J, Takahashi JS. 2011. Circadian rhythms: redox redux. Nature 469: 476-478. doi:10.1038/469476a

Beaulé C, Swanstrom A, Leone MJ, Herzog ED. 2009. Circadian modulation of gene expression, but not glutamate uptake, in mouse and rat cortical astrocytes. PLoS One 4: e7476. doi:10 .1371 /journal.pone.0007476

Beier KT, Steinberg EE, DeLoach KE, Xie S, Miyamichi K, Schwarz L, Gao XJ, Kremer EJ, Malenka RC, Luo L. 2015. Circuit architecture of VTA dopamine neurons revealed by systematic input-output mapping. Cell 162: 622-634. doi:10 $.1016 /$ j.cell.2015.07.015

Bero AW, Yan P, Roh JH, Cirrito JR, Stewart FR, Raichle ME, Lee JM, Holtzman DM. 2011. Neuronal activity regulates the regional vulnerability to amyloid- $\beta$ deposition. Nat Neurosci 14: 750-756. doi:10.1038/nn.2801

Bookout AL, de Groot MH, Owen BM, Lee S, Gautron L, Lawrence HL, Ding X, Elmquist JK, Takahashi JS, Mangelsdorf DJ, et al. 2013. FGF21 regulates metabolism and circadian behavior by acting on the nervous system. Nat Med 19: 1147-1152. doi:10.1038/nm.3249

Bouchard-Cannon P, Cheng HY. 2012. Scheduled feeding alters the timing of the suprachiasmatic nucleus circadian clock in dexras1-deficient mice. Chronobiol Int 29: 965-981. doi:10 .3109/07420528.2012.707264

Brancaccio M, Patton AP, Chesham JE, Maywood ES, Hastings MH. 2017. Astrocytes control circadian timekeeping in the suprachiasmatic nucleus via glutamatergic signaling. Neuron 93: 1420-1435.e5. doi:10.1016/j.neuron.2017.02.030

Brancaccio M, Edwards MD, Patton AP, Smyllie NJ, Chesham JE, Maywood ES, Hastings MH. 2019. Cell-autonomous clock of astrocytes drives circadian behavior in mammals. Science 363: 187-192. doi:10.1126/science.aat4104

Brown SA, Ripperger J, Kadener S, Fleury-Olela F, Vilbois F, Rosbash M, Schibler U. 2005. PERIOD1-associated proteins modulate the negative limb of the mammalian circadian oscillator. Science 308: 693-696. doi:10.1126/science .1107373 
Buhr ED, Yoo SH, Takahashi JS. 2010. Temperature as a universal resetting cue for mammalian circadian oscillators. Science 330: 379-385. doi:10.1126/science.1195262

Busino L, Bassermann F, Maiolica A, Lee C, Nolan PM, Godinho SI, Draetta GF, Pagano M. 2007. SCFFbxl3 controls the oscillation of the circadian clock by directing the degradation of cryptochrome proteins. Science 316: 900-904. doi:10.1126/sci ence. 1141194

Campbell JN, Macosko EZ, Fenselau H, Pers TH, Lyubetskaya A, Tenen D, Goldman M, Verstegen AM, Resch JM, McCarroll SA, et al. 2017. A molecular census of arcuate hypothalamus and median eminence cell types. Nat Neurosci 20: 484-496. doi: $10.1038 / \mathrm{nn} .4495$

Cao G, Nitabach MN. 2008. Circadian control of membrane excitability in Drosophila melanogaster lateral ventral clock neurons. J Neurosci 28: 6493-6501. doi:10.1523/JNEUROSCI $.1503-08.2008$

Cao R, Robinson B, Xu H, Gkogkas C, Khoutorsky A, Alain T, Yanagiya A, Nevarko T, Liu AC, Amir S, et al. 2013. Translational control of entrainment and synchrony of the suprachiasmatic circadian clock by mTOR/4E-BP1 signaling. Neuron 79: 712-724. doi:10.1016/j.neuron.2013.06.026

Castañeda TR, de Prado BM, Prieto D, Mora F. 2004. Circadian rhythms of dopamine, glutamate and GABA in the striatum and nucleus accumbens of the awake rat: modulation by light. I Pineal Res 36: 177-185. doi:10.1046/j.1600-079X.2003 $.00114 . x$

Caster SZ, Castillo K, Sachs MS, Bell-Pedersen D. 2016. Circadian clock regulation of mRNA translation through eukaryotic elongation factor eEF-2. Proc Natl Acad Sci 113: 9605-9610. doi:10.1073/pnas.1525268113

Cedernaes J, Osorio RS, Varga AW, Kam K, Schiöth HB, Benedict C. 2017. Candidate mechanisms underlying the association between sleep-wake disruptions and Alzheimer's disease. Sleep Med Rev 31: 102-111. doi:10.1016/j.smrv.2016.02.002

Cedernaes J, Huang W, Ramsey KM, Waldeck N, Cheng L, Marcheva B, Omura C, Kobayashi Y, Peek CB, Levine DC, et al. 2019. Transcriptional basis for rhythmic control of hunger and metabolism within the AgRP neuron. Cell Metab 29: 1078-1091.e5. doi:10.1016/j.cmet.2019.01.023

Chang HC, Guarente L. 2013. SIRT1 mediates central circadian control in the SCN by a mechanism that decays with aging. Cell 153: 1448-1460. doi:10.1016/j.cell.2013.05.027

Chen D, Buchanan GF, Ding JM, Hannibal J, Gillette MU. 1999. Pituitary adenylyl cyclase-activating peptide: a pivotal modulator of glutamatergic regulation of the suprachiasmatic circadian clock. Proc Natl Acad Sci 96: 13468-13473. doi:10.1073/ pnas.96.23.13468

Cheng HY, Obrietan K, Cain SW, Lee BY, Agostino PV, Joza NA, Harrington ME, Ralph MR, Penninger JM. 2004. Dexras1 potentiates photic and suppresses nonphotic responses of the circadian clock. Neuron 43: 715-728. doi:10.1016/j.neuron.2004 .08 .021

Chou TC, Scammell TE, Gooley JJ, Gaus SE, Saper CB, Lu J. 2003. Critical role of dorsomedial hypothalamic nucleus in a wide range of behavioral circadian rhythms. J Neurosci 23: 1069110702. doi:10.1523/JNEUROSCI.23-33-10691.2003

Chun SJ, Niijima A, Nagai N, Nagai K. 1998. Effect of bilateral lesions of the suprachiasmatic nucleus on hyperglycemia caused by 2-deoxy-D-glucose and vasoactive intestinal peptide in rats. Brain Res 809: 165-174. doi:10.1016/S0006-8993 (98)00854-3

Chung WS, Clarke LE, Wang GX, Stafford BK, Sher A, Chakraborty C, Joung J, Foo LC, Thompson A, Chen C, et al. 2013. Astrocytes mediate synapse elimination through MEGF10 and
MERTK pathways. Nature 504: 394-400. doi:10.1038/ nature 12776

Chung S, Weber F, Zhong P, Tan CL, Nguyen TN, Beier KT, Hörmann N, Chang WC, Zhang Z, Do JP, et al. 2017. Identification of preoptic sleep neurons using retrograde labelling and gene profiling. Nature 545: 477-481. doi:10.1038/nature22350

Cipolla-Neto J, Amaral FG, Afeche SC, Tan DX, Reiter RJ. 2014. Melatonin, energy metabolism, and obesity: a review. J Pineal Res 56: 371-381. doi:10.1111/jpi.12137

Cirelli C, Gutierrez CM, Tononi G. 2004. Extensive and divergent effects of sleep and wakefulness on brain gene expression. Neuron 41: 35-43. doi:10.1016/S0896-6273(03)00814-6

Cirrito JR, Deane R, Fagan AM, Spinner ML, Parsadanian M, Finn MB, Jiang H, Prior JL, Sagare A, Bales KR, et al. 2005. P-glycoprotein deficiency at the blood-brain barrier increases amyloid- $\beta$ deposition in an Alzheimer disease mouse model. J Clin Invest 115: 3285-3290. doi:10.1172/JCI25247

Cohen RA, Albers HE. 1991. Disruption of human circadian and cognitive regulation following a discrete hypothalamic lesion: a case study. Neurology 41: 726-729. doi:10.1212/WNL.41.5 .726

Coomans CP, van den Berg SA, Lucassen EA, Houben T, Pronk AC, van der Spek RD, Kalsbeek A, Biermasz NR, van Dijk K W, Romijn JA, et al. 2013. The suprachiasmatic nucleus controls circadian energy metabolism and hepatic insulin sensitivity. Diabetes 62: 1102-1108. doi:10.2337/db12-0507

Cooper SJ. 2008. From Claude Bernard to Walter Cannon. Emergence of the concept of homeostasis. Appetite 51: 419-427. doi:10.1016/j.appet.2008.06.005

Costa-Mattioli M, Sossin WS, Klann E, Sonenberg N. 2009. Translational control of long-lasting synaptic plasticity and memory. Neuron 61: 10-26. doi:10.1016/j.neuron.2008.10.055

Crosio C, Cermakian N, Allis CD, Sassone-Corsi P. 2000. Light induces chromatin modification in cells of the mammalian circadian clock. Nat Neurosci 3: 1241-1247. doi:10.1038/ 81767

Cutler DJ, Haraura M, Reed HE, Shen S, Sheward WI, Morrison CF, Marston HM, Harmar AJ, Piggins HD. 2003. The mouse VPAC2 receptor confers suprachiasmatic nuclei cellular rhythmicity and responsiveness to vasoactive intestinal polypeptide in vitro. Eur I Neurosci 17: 197-204. doi:10.1046/j $.1460-9568.2003 .02425 . \mathrm{x}$

Czeisler CA, Zimmerman JC, Ronda JM, Moore-Ede MC, Weitzman ED. 1980. Timing of REM sleep is coupled to the circadian rhythm of body temperature in man. Sleep 2: 329-346. doi:10.1093/sleep/2.3.329

Czeisler CA, Duffy JF, Shanahan TL, Brown EN, Mitchell JF, Rimmer DW, Ronda JM, Silva EJ, Allan JS, Emens JS, et al. 1999. Stability, precision, and near-24-hour period of the human circadian pacemaker. Science 284: 2177-2181. doi:10 $.1126 /$ science.284.5423.2177

Dai J, Swaab DF, Van der Vliet J, Buijs RM. 1998. Postmortem tracing reveals the organization of hypothalamic projections of the suprachiasmatic nucleus in the human brain. J Comp Neurol 400: 87-102. doi:10.1002/(SICI)1096-9861(19981012) 400:1<87::AID-CNE6>3.0.CO;2-P

Damiola F, Le Minh N, Preitner N, Kornmann B, Fleury-Olela F, Schibler U. 2000. Restricted feeding uncouples circadian oscillators in peripheral tissues from the central pacemaker in the suprachiasmatic nucleus. Genes Dev 14: 2950-2961. doi:10.1101/gad.183500

Deurveilher S, Burns J, Semba K. 2002. Indirect projections from the suprachiasmatic nucleus to the ventrolateral preoptic nucleus: a dual tract-tracing study in rat. Eur J Neurosci 16: 11951213. doi:10.1046/j.1460-9568.2002.02196.x 
Dibner C, Schibler U, Albrecht U. 2010. The mammalian circadian timing system: organization and coordination of central and peripheral clocks. Annu Rev Physiol 72: 517-549. doi:10 .1146/annurev-physiol-021909-135821

Dietrich MO, Liu ZW, Horvath TL. 2013. Mitochondrial dynamics controlled by mitofusins regulate Agrp neuronal activity and diet-induced obesity. Cell 155: 188-199. doi:10.1016/j .cell.2013.09.004

Ding JM, Chen D, Weber ET, Faiman LE, Rea MA, Gillette MU. 1994. Resetting the biological clock: mediation of nocturnal circadian shifts by glutamate and NO. Science 266: 17131717. doi:10.1126/science. 7527589

Ding F, O'Donnell J, Xu Q, Kang N, Goldman N, Nedergaard M. 2016. Changes in the composition of brain interstitial ions control the sleep-wake cycle. Science 352: 550-555. doi:10 $.1126 /$ science.aad 4821

Dodd GT, Worth AA, Nunn N, Korpal AK, Bechtold DA, Allison MB, Myers MG Jr, Statnick MA, Luckman SM. 2014. The thermogenic effect of leptin is dependent on a distinct population of prolactin-releasing peptide neurons in the dorsomedial hypothalamus. Cell Metab 20: 639-649. doi:10.1016/j.cmet .2014 .07 .022

Dulcis D, Spitzer NC. 2008. Illumination controls differentiation of dopamine neurons regulating behaviour. Nature 456: 195201. doi:10.1038/nature07569

Dulcis D, Jamshidi P, Leutgeb S, Spitzer NC. 2013. Neurotransmitter switching in the adult brain regulates behavior. Science 340: 449-453. doi:10.1126/science.1234152

Eckel-Mahan KL, Patel VR, de Mateo S, Orozco-Solis R, Ceglia NJ, Sahar S, Dilag-Penilla SA, Dyar KA, Baldi P, Sassone-Corsi P. 2013. Reprogramming of the circadian clock by nutritional challenge. Cell 155: 1464-1478. doi:10.1016/j.cell.2013.11 .034

Edgar DM, Dement WC, Fuller CA. 1993. Effect of SCN lesions on sleep in squirrel monkeys: evidence for opponent processes in sleep-wake regulation. I Neurosci 13: 1065-1079. doi:10 .1523/JNEUROSCI.13-03-01065.1993

Edgar DM, Reid MS, Dement WC. 1997. Serotonergic afferents mediate activity-dependent entrainment of the mouse circadian clock. Am J Physiol 273: R265-R269.

Ehlen JC, Brager AJ, Baggs J, Pinckney L, Gray CL, DeBruyne JP, Esser KA, Takahashi JS, Paul KN. 2017. Bmall function in skeletal muscle regulates sleep. Elife 6: e26557. doi:10.7554/ eLife. 26557

Eide EJ, Woolf MF, Kang H, Woolf P, Hurst W, Camacho F, Vielhaber EL, Giovanni A, Virshup DM. 2005. Control of mammalian circadian rhythm by CKIs-regulated proteasomemediated PER2 degradation. Mol Cell Biol 25: 2795-2807. doi:10.1128/MCB.25.7.2795-2807.2005

Elmquist JK, Ahima RS, Elias CF, Flier JS, Saper CB. 1998. Leptin activates distinct projections from the dorsomedial and ventromedial hypothalamic nuclei. Proc Natl Acad Sci 95: 741746. doi:10.1073/pnas.95.2.741

Erion R, King AN, Wu G, Hogenesch JB, Sehgal A. 2016. Neural clocks and neuropeptide $\mathrm{F} / \mathrm{Y}$ regulate circadian gene expression in a peripheral metabolic tissue. Elife 5: e13552. doi:10 $.7554 /$ eLife. 13552

Fang B, Everett LJ, Jager I, Briggs E, Armour SM, Feng D, Roy A, Gerhart-Hines Z, Sun Z, Lazar MA. 2014. Circadian enhancers coordinate multiple phases of rhythmic gene transcription in vivo. Cell 159: 1140-1152. doi:10.1016/j.cell.2014.10.022

Ferrari LL, Park D, Zhu L, Palmer MR, Broadhurst RY, Arrigoni E. 2018. Regulation of lateral hypothalamic orexin activity by local GABAergic neurons. I Neurosci 38: 1588-1599. doi:10 .1523/JNEUROSCI.1925-17.2017
Flourakis M, Kula-Eversole E, Hutchison AL, Han TH, Aranda K, Moose DL, White KP, Dinner AR, Lear BC, Ren D, et al. 2015. A conserved bicycle model for circadian clock control of membrane excitability. Cell 162: 836-848. doi:10.1016/j.cell .2015.07.036

Fogel BL, Wexler E, Wahnich A, Friedrich T, Vijayendran C, Gao F, Parikshak N, Konopka G, Geschwind DH. 2012. RBFOX1 regulates both splicing and transcriptional networks in human neuronal development. Hum Mol Genet 21: 41714186. doi:10.1093/hmg/dds240

Fontenot MR, Berto S, Liu Y, Werthmann G, Douglas C, Usui N, Gleason K, Tamminga CA, Takahashi JS, Konopka G. 2017. Novel transcriptional networks regulated by CLOCK in human neurons. Genes Dev 31: 2121-2135. doi:10.1101/gad .305813 .117

Freedman MS, Lucas RJ, Soni B, von Schantz M, Munoz M, David-Gray Z, Foster R. 1999. Regulation of mammalian circadian behavior by non-rod, non-cone, ocular photoreceptors. Science 284: 502-504. doi:10.1126/science.284.5413.502

Freeman GM Jr, Krock RM, Aton SJ, Thaben P, Herzog ED. 2013. GABA networks destabilize genetic oscillations in the circadian pacemaker. Neuron 78: 799-806. doi:10.1016/j.neuron .2013 .04 .003

Fuller PM, Lu J, Saper CB. 2008. Differential rescue of light- and food-entrainable circadian rhythms. Science 320: 1074-1077. doi:10.1126/science.1153277

Funato H, Miyoshi C, Fujiyama T, Kanda T, Sato M, Wang Z, Ma J, Nakane S, Tomita J, Ikkyu A, et al. 2016. Forward-genetics analysis of sleep in randomly mutagenized mice. Nature 539: 378-383. doi:10.1038/nature20142

Gallego M, Virshup DM. 2007. Post-translational modifications regulate the ticking of the circadian clock. Nat Rev Mol Cell Biol 8: 139-148. doi:10.1038/nrm2106

Garfield AS, Shah BP, Burgess CR, Li MM, Li C, Steger JS, Madara JC, Campbell JN, Kroeger D, Scammell TE, et al. 2016. Dynamic GABAergic afferent modulation of AgRP neurons. Nat Neurosci 19: 1628-1635. doi:10.1038/nn.4392

Gau D, Lemberger T, von Gall C, Kretz O, Le Minh N, Gass P, Schmid W, Schibler U, Korf HW, Schütz G. 2002. Phosphorylation of CREB Ser142 regulates light-induced phase shifts of the circadian clock. Neuron 34: 245-253. doi:10.1016/S08966273(02)00656-6

Geiser F. 2004. Metabolic rate and body temperature reduction during hibernation and daily torpor. Annu Rev Physiol 66: 239-274. doi:10.1146/annurev.physiol.66.032102.115105

Gerhart-Hines Z, Feng D, Emmett MJ, Everett LJ, Loro E, Briggs ER, Bugge A, Hou C, Ferrara C, Seale P, et al. 2013. The nuclear receptor Rev-erba controls circadian thermogenic plasticity. Nature 503: 410-413. doi:10.1038/nature12642

Ghamari-Langroudi M, Srisai D, Cone RD. 2011. Multinodal regulation of the arcuate/paraventricular nucleus circuit by leptin. Proc Natl Acad Sci 108: 355-360. doi:10.1073/pnas .1016785108

Gizowski C, Zaelzer C, Bourque CW. 2016. Clock-driven vasopressin neurotransmission mediates anticipatory thirst prior to sleep. Nature 537: 685-688. doi:10.1038/nature19756

Godinho SI, Maywood ES, Shaw L, Tucci V, Barnard AR, Busino L, Pagano M, Kendall R, Quwailid MM, Romero MR, et al. 2007. The after-hours mutant reveals a role for Fbxl3 in determining mammalian circadian period. Science 316: 897-900. doi:10 $.1126 /$ science. 1141138

Goldsmith CS, Bell-Pedersen D. 2013. Diverse roles for MAPK signaling in circadian clocks. Adv Genet 84: 1-39. doi:10 .1016/B978-0-12-407703-4.00001-3 
Goldstein N, Levine BJ, Loy KA, Duke WL, Meyerson OS, Jamnik AA, Carter ME. 2018. Hypothalamic neurons that regulate feeding can influence sleep/wake states based on homeostatic need. Curr Biol 28: 3736-3747.e3. doi:10.1016/j.cub.2018.09 .055

Gooley JJ, Lu J, Chou TC, Scammell TE, Saper CB. 2001. Melanopsin in cells of origin of the retinohypothalamic tract. Nat Neurosci 4: 1165. doi:10.1038/nn768

Gotic I, Omidi S, Fleury-Olela F, Molina N, Naef F, Schibler U. 2016. Temperature regulates splicing efficiency of the cold-inducible RNA-binding protein gene Cirbp. Genes Dev 30: 2005-2017. doi:10.1101/gad.287094.116

Green CB. 2018. Circadian posttranscriptional regulatory mechanisms in mammals. Cold Spring Harb Perspect Biol 10: a030692. doi:10.1101/cshperspect.a030692

Greenberg ME, Ziff EB. 1984. Stimulation of 3T3 cells induces transcription of the c-fos proto-oncogene. Nature 311: 433438. doi:10.1038/311433a0

Greenwell BJ, Trott AJ, Beytebiere JR, Pao S, Bosley A, Beach E, Finegan P, Hernandez C, Menet JS. 2019. Rhythmic food intake drives rhythmic gene expression more potently than the hepatic circadian clock in mice. Cell Rep 27: 649657.e5. doi:10.1016/j.celrep.2019.03.064

Grippo RM, Purohit AM, Zhang Q, Zweifel LS, Güler AD. 2017. Direct midbrain dopamine input to the suprachiasmatic nucleus accelerates circadian entrainment. Curr Biol 27: 24652475.e3. doi:10.1016/j.cub.2017.06.084

Guan D, Xiong Y, Borck PC, Jang C, Doulias P-T, Papazyan R, Fang B, Jiang C, Zhang Y, Briggs ER, et al. 2018. Diet-induced circadian enhancer remodeling synchronizes opposing hepatic lipid metabolic processes. Cell 174: 831-842.e12. doi:10 $.1016 /$ j.cell.2018.06.031

Güler AD, Ecker JL, Lall GS, Haq S, Altimus CM, Liao HW, Barnard AR, Cahill H, Badea TC, Zhao H, et al. 2008. Melanopsin cells are the principal conduits for rod-cone input to non-image-forming vision. Nature 453: 102-105. doi:10.1038/ nature06829

Guo H, Brewer JM, Champhekar A, Harris RB, Bittman EL. 2005. Differential control of peripheral circadian rhythms by suprachiasmatic-dependent neural signals. Proc Natl Acad Sci 102: 3111-3116. doi:10.1073/pnas.0409734102

Haam J, Popescu IR, Morton LA, Halmos KC, Teruyama R, Ueta $\mathrm{Y}$, Tasker JG. 2012. GABA is excitatory in adult vasopressinergic neuroendocrine cells. J Neurosci 32: 572-582. doi:10.1523/ JNEUROSCI.3826-11.2012

Haj-Yasein NN, Vindedal GF, Eilert-Olsen M, Gundersen GA, Skare O, Laake P, Klungland A, Thoren AE, Burkhardt JM, Ottersen OP, et al. 2011. Glial-conditional deletion of aquaporin-4 (Aqp4) reduces blood-brain water uptake and confers barrier function on perivascular astrocyte endfeet. Proc Natl Acad Sci 108: 17815-17820. doi:10.1073/pnas.1110655108

Hampp G, Ripperger JA, Houben T, Schmutz I, Blex C, PerreauLenz S, Brunk I, Spanagel R, Ahnert-Hilger G, Meijer JH, et al. 2008. Regulation of monoamine oxidase A by circadian-clock components implies clock influence on mood. Curr Biol 18: 678-683. doi:10.1016/j.cub.2008.04.012

Hannibal J, Ding JM, Chen D, Fahrenkrug J, Larsen PJ, Gillette MU, Mikkelsen JD. 1997. Pituitary adenylate cyclase-activating peptide (PACAP) in the retinohypothalamic tract: a potential daytime regulator of the biological clock. J Neurosci 17: 2637-2644. doi:10.1523/JNEUROSCI.17-07-02637.1997

Harmar AJ, Marston HM, Shen S, Spratt C, West KM, Sheward WJ, Morrison CF, Dorin JR, Piggins HD, Reubi JC, et al. 2002. The VPAC(2) receptor is essential for circadian function in the mouse suprachiasmatic nuclei. Cell 109: 497-508. doi:10.1016/S0092-8674(02)00736-5

Harrington ME, Hoque S, Hall A, Golombek D, Biello S. 1999. Pituitary adenylate cyclase activating peptide phase shifts circadian rhythms in a manner similar to light. I Neurosci 19: 6637-6642. doi:10.1523/JNEUROSCI.19-15-06637.1999

Hatori M, Vollmers C, Zarrinpar A, DiTacchio L, Bushong EA, Gill S, Leblanc M, Chaix A, Joens M, Fitzpatrick JA, et al. 2012. Time-restricted feeding without reducing caloric intake prevents metabolic diseases in mice fed a high-fat diet. Cell Metab 15: 848-860. doi:10.1016/j.cmet.2012.04.019

Hattar S, Kumar M, Park A, Tong P, Tung J, Yau KW, Berson DM. 2006. Central projections of melanopsin-expressing retinal ganglion cells in the mouse. I Comp Neurol 497: 326-349. doi:10.1002/cne.20970

Hayashi Y, Koyanagi S, Kusunose N, Okada R, Wu Z, Tozaki-Saitoh H, Ukai K, Kohsaka S, Inoue K, Ohdo S, et al. 2013. The intrinsic microglial molecular clock controls synaptic strength via the circadian expression of cathepsin S. Sci Rep 3: 2744. doi:10.1038/srep02744

Heisler LK, Jobst EE, Sutton GM, Zhou L, Borok E, ThorntonJones Z, Liu HY, Zigman JM, Balthasar N, Kishi T, et al. 2006. Serotonin reciprocally regulates melanocortin neurons to modulate food intake. Neuron 51: 239-249. doi:10.1016/j .neuron.2006.06.004

Henry FE, Sugino K, Tozer A, Branco T, Sternson SM. 2015. Cell type-specific transcriptomics of hypothalamic energy-sensing neuron responses to weight-loss. Elife 4: e09800. doi:10.7554/ eLife.09800

Herzog ED, Takahashi JS, Block GD. 1998. Clock controls circadian period in isolated suprachiasmatic nucleus neurons. Nat Neurosci 1: 708-713. doi:10.1038/3708

Hirano A, Hsu PK, Zhang L, Xing L, McMahon T, Yamazaki M, Ptáček LJ, Fu YH. 2018. DEC2 modulates orexin expression and regulates sleep. Proc Natl Acad Sci 115: 3434-3439. doi:10.1073/pnas.1801693115

Hong HK, Maury E, Ramsey KM, Perelis M, Marcheva B, Omura C, Kobayashi Y, Guttridge DC, Barish GD, Bass J. 2018. Requirement for NF- $\mathrm{kB}$ in maintenance of molecular and behavioral circadian rhythms in mice. Genes Dev 32: 1367-1379. doi:10.1101/gad.319228.118

Horvath TL, Abizaid A, Dietrich MO, Li Y, Takahashi JS, Bass J. 2012. Ghrelin-immunopositive hypothalamic neurons tie the circadian clock and visual system to the lateral hypothalamic arousal center. Mol Metab 1: 79-85. doi:10.1016/j.molmet .2012 .08 .003

Hu WP, Li JD, Colwell CS, Zhou QY. 2011. Decreased REM sleep and altered circadian sleep regulation in mice lacking vasoactive intestinal polypeptide. Sleep 34: 49-56. doi:10.1093/ sleep/34.1.49

Hu Y, Shmygelska A, Tran D, Eriksson N, Tung JY, Hinds DA. 2016. GWAS of 89,283 individuals identifies genetic variants associated with self-reporting of being a morning person. Nat Commun 7: 10448. doi:10.1038/ncomms 10448

Hughes ME, Hong HK, Chong JL, Indacochea AA, Lee SS, Han M, Takahashi JS, Hogenesch JB. 2012. Brain-specific rescue of Clock reveals system-driven transcriptional rhythms in peripheral tissue. PLoS Genet 8: e1002835. doi:10.1371/journal .pgen.1002835

Iliff JJ, Wang M, Liao Y, Plogg BA, Peng W, Gundersen GA, Benveniste H, Vates GE, Deane R, Goldman SA, et al. 2012. A paravascular pathway facilitates CSF flow through the brain parenchyma and the clearance of interstitial solutes, including amyloid $\beta$. Sci Transl Med 4: 147ra111. doi:10.1126/sci translmed.3003748 
Inyushkin AN, Bhumbra GS, Dyball RE. 2009. Leptin modulates spike coding in the rat suprachiasmatic nucleus. I Neuroendocrinol 21: 705-714. doi:10.1111/j.1365-2826.2009.01889.x

Ioannou MS, Jackson J, Sheu S, Chang C, Weigel AV, Pasolli HA, Xu CS, Pang S, Matthies D, Hess HF, et al. 2019. Neuron-astrocyte metabolic coupling protects against activity-induced fatty acid toxicity. Cell 177: 1522-1535.e14. 10.1016/j.cell .2019.1004.1001

Izumo M, Pejchal M, Schook AC, Lange RP, Walisser JA, Sato TR, Wang X, Bradfield CA, Takahashi JS. 2014. Differential effects of light and feeding on circadian organization of peripheral clocks in a forebrain Bmal1 mutant. Elife 3: e04617. doi:10 .7554/eLife.04617

Jakubcakova V, Oster H, Tamanini F, Cadenas C, Leitges M, van der Horst GT, Eichele G. 2007. Light entrainment of the mammalian circadian clock by a PRKCA-dependent posttranslational mechanism. Neuron 54: 831-843. doi:10.1016/j .neuron.2007.04.031

Janich P, Arpat AB, Castelo-Szekely V, Lopes M, Gatfield D. 2015. Ribosome profiling reveals the rhythmic liver translatome and circadian clock regulation by upstream open reading frames. Genome Res 25: 1848-1859. doi:10.1101/gr.195404 .115

Jones SE, Tyrrell J, Wood AR, Beaumont RN, Ruth KS, Tuke MA, Yaghootkar H, Hu Y, Teder-Laving M, Hayward C, et al. 2016. Genome-Wide association analyses in 128,266 individuals identifies new morningness and sleep duration loci. PLoS Genet 12: e1006125. doi:10.1371/journal.pgen.1006125

Jones JR, Simon T, Lones L, Herzog ED. 2018. SCN VIP neurons are essential for normal light-mediated resetting of the circadian system. J Neurosci 38: 7986-7995. doi:10.1523/JNEURO SCI.1322-18.2018

Jouffe C, Cretenet G, Symul L, Martin E, Atger F, Naef F, Gachon F. 2013. The circadian clock coordinates ribosome biogenesis. PLOS Biol 11: e1001455. doi:10.1371/journal.pbio.1001455

Kang L, Dunn-Meynell AA, Routh VH, Gaspers LD, Nagata Y, Nishimura T, Eiki J, Zhang BB, Levin BE. 2006. Glucokinase is a critical regulator of ventromedial hypothalamic neuronal glucosensing. Diabetes 55: 412-420. doi:10.2337/diabetes.55 .02.06.db05-1229

Kempf A, Song SM, Talbot CB, Miesenböck G. 2019. A potassium channel $\beta$-subunit couples mitochondrial electron transport to sleep. Nature 568: 230-234. doi:10.1038/s41586-0191034-5

Kettner NM, Mayo SA, Hua J, Lee C, Moore DD, Fu L. 2015. Circadian dysfunction induces leptin resistance in mice. Cell Metab 22: 448-459. doi:10.1016/j.cmet.2015.06.005

Kim JG, Suyama S, Koch M, Jin S, Argente-Arizon P, Argente J, Liu ZW, Zimmer MR, Jeong JK, Szigeti-Buck K, et al. 2014. Leptin signaling in astrocytes regulates hypothalamic neuronal circuits and feeding. Nat Neurosci 17: 908-910. doi:10 $.1038 / \mathrm{nn} .3725$

Kim YH, Marhon SA, Zhang Y, Steger DJ, Won K-J, Lazar MA. 2018. Rev-erba dynamically modulates chromatin looping to control circadian gene transcription. Science 359: 12741277. doi:10.1126/science.aao6891

Knight ZA, Tan K, Birsoy K, Schmidt S, Garrison JL, Wysocki RW, Emiliano A, Ekstrand MI, Friedman JM. 2012. Molecular profiling of activated neurons by phosphorylated ribosome capture. Cell 151: 1126-1137. doi:10.1016/j.cell.2012.10.039

Kohno D, Lee S, Harper MJ, Kim KW, Sone H, Sasaki T, Kitamura T, Fan G, Elmquist JK. 2014. Dnmt3a in Sim1 neurons is necessary for normal energy homeostasis. J Neurosci 34: 1528815296. doi:10.1523/JNEUROSCI.1316-14.2014
Kohsaka A, Laposky AD, Ramsey KM, Estrada C, Joshu C, Kobayashi Y, Turek FW, Bass J. 2007a. High-fat diet disrupts behavioral and molecular circadian rhythms in mice. Cell Metab 6: 414-421. doi:10.1016/j.cmet.2007.09.006

Koike N, Yoo SH, Huang HC, Kumar V, Lee C, Kim TK, Takahashi JS. 2012. Transcriptional architecture and chromatin landscape of the core circadian clock in mammals. Science 338: 349-354. doi:10.1126/science.1226339

Konopka G, Friedrich T, Davis-Turak J, Winden K, Oldham MC, Gao F, Chen L, Wang G-Z, Luo R, Preuss TM, et al. 2012. Human-specific transcriptional networks in the brain. Neuron 75: 601-617. doi:10.1016/j.neuron.2012.05.034

Kornhauser JM, Nelson DE, Mayo KE, Takahashi JS. 1990. Photic and circadian regulation of $c$-fos gene expression in the hamster suprachiasmatic nucleus. Neuron 5: 127-134. doi:10 .1016/0896-6273(90)90303-W

Kornmann B, Schaad O, Bujard H, Takahashi JS, Schibler U. 2007. System-driven and oscillator-dependent circadian transcription in mice with a conditionally active liver clock. PLOS Biol 5: e34. doi:10.1371/journal.pbio.0050034

Krashes MJ, Shah BP, Koda S, Lowell BB. 2013. Rapid versus delayed stimulation of feeding by the endogenously released AgRP neuron mediators GABA, NPY, and AgRP. Cell Metab 18: 588-595. doi:10.1016/j.cmet.2013.09.009

Krashes MJ, Shah BP, Madara JC, Olson DP, Strochlic DE, Garfield AS, Vong L, Pei H, Watabe-Uchida M, Uchida N, et al. 2014. An excitatory paraventricular nucleus to AgRP neuron circuit that drives hunger. Nature 507: 238-242. doi:10 $.1038 /$ nature 12956

Kriegsfeld LJ, Silver R. 2006. The regulation of neuroendocrine function: timing is everything. Horm Behav 49: 557-574. doi:10.1016/j.yhbeh.2005.12.011

Kwapis JL, Alaghband Y, Kramar EA, López AJ, Vogel Ciernia A, White AO, Shu G, Rhee D, Michael CM, Montellier E, et al. 2018. Epigenetic regulation of the circadian gene Perl contributes to age-related changes in hippocampal memory. Nat Commun 9: 3323. doi:10.1038/s41467-018-05868-0

la Fleur SE, Kalsbeek A, Wortel J, Buijs RM. 2000. Polysynaptic neural pathways between the hypothalamus, including the suprachiasmatic nucleus, and the liver. Brain Res 871: 50-56. doi:10.1016/S0006-8993/00/02423-9

Lamia KA, Storch KF, Weitz CJ. 2008. Physiological significance of a peripheral tissue circadian clock. Proc Natl Acad Sci 105: 15172-15177. doi:10.1073/pnas.0806717105

Lamia KA, Sachdeva UM, DiTacchio L, Williams EC, Alvarez JG, Egan DF, Vasquez DS, Juguilon H, Panda S, Shaw RJ, et al. 2009. AMPK regulates the circadian clock by cryptochrome phosphorylation and degradation. Science 326: 437-440. doi:10.1126/science.1172156

Landry GJ, Yamakawa GR, Webb IC, Mear RJ, Mistlberger RE. 2007. The dorsomedial hypothalamic nucleus is not necessary for the expression of circadian food-anticipatory activity in rats. I Biol Rhythms 22: 467-478. doi:10.1177/074873 0407307804

Laposky A, Easton A, Dugovic C, Walisser J, Bradfield C, Turek F. 2005. Deletion of the mammalian circadian clock gene BMAL1/Mop3 alters baseline sleep architecture and the response to sleep deprivation. Sleep 28: 395-410. doi:10.1093/ sleep/28.4.395

Laposky AD, Shelton J, Bass J, Dugovic C, Perrino N, Turek FW. 2006. Altered sleep regulation in leptin-deficient mice. Am I Physiol Regul Integr Comp Physiol 290: R894-R903. doi:10 .1152/ajpregu.00304.2005

Lee IT, Chang AS, Manandhar M, Shan Y, Fan J, Izumo M, Ikeda Y, Motoike T, Dixon S, Seinfeld JE, et al. 2015. Neuromedin s- 
producing neurons act as essential pacemakers in the suprachiasmatic nucleus to couple clock neurons and dictate circadian rhythms. Neuron 85: 1086-1102. doi:10.1016/j.neuron .2015.02.006

Li Q, Kellner DA, Hatch HAM, Yumita T, Sanchez S, Machold RP, Frank CA, Stavropoulos N. 2017. Conserved properties of Drosophila Insomniac link sleep regulation and synaptic function. PLoS Genet 13: e1006815. doi:10.1371/journal .pgen.1006815

Lim C, Allada R. 2013. Emerging roles for post-transcriptional regulation in circadian clocks. Nat Neurosci 16: 1544-1550. doi: $10.1038 / \mathrm{nn} .3543$

Lim C, Lee J, Choi C. 2011. The novel gene twenty-four defines a critical translational step in the Drosophila clock. Nature 470: 399-403.

Lind RW, Van Hoesen GW, Johnson AK. 1982. An HRP study of the connections of the subfornical organ of the rat. J Comp Neurol 210: 265-277. doi:10.1002/cne.902100306

Lipton JO, Yuan ED, Boyle LM, Ebrahimi-Fakhari D, Kwiatkowski E, Nathan A, Güttler T, Davis F, Asara JM, Sahin M. 2015. The circadian protein BMAL1 regulates translation in response to S6K1-mediated phosphorylation. Cell 161: 11381151. doi:10.1016/j.cell.2015.04.002

Liu C, Li S, Liu T, Borjigin J, Lin JD. 2007. Transcriptional coactivator PGC-1 $1 a$ integrates the mammalian clock and energy metabolism. Nature 447: 477-481. doi:10.1038/nature05767

Liu T, Kong D, Shah BP, Ye C, Koda S, Saunders A, Ding JB, Yang Z, Sabatini BL, Lowell BB. 2012. Fasting activation of AgRP neurons requires NMDA receptors and involves spinogenesis and increased excitatory tone. Neuron 73: 511-522. doi:10 .1016/j.neuron.2011.11.027

Liu K, Kim J, Kim DW, Zhang YS, Bao H, Denaxa M, Lim SA, Kim E, Liu C, Wickersham IR, et al. 2017. Lhx6-positive GABA-releasing neurons of the zona incerta promote sleep. Nature 548: 582-587. doi:10.1038/nature23663

Lowrey PL, Shimomura K, Antoch MP, Yamazaki S, Zemenides PD, Ralph MR, Menaker M, Takahashi JS. 2000. Positional syntenic cloning and functional characterization of the mammalian circadian mutation tau. Science 288: 483-491. doi:10 $.1126 /$ science. 288.5465 .483

Lundgaard I, Lu ML, Yang E, Peng W, Mestre H, Hitomi E, Deane R, Nedergaard M. 2017. Glymphatic clearance controls statedependent changes in brain lactate concentration. I Cereb Blood Flow Metab 37: 2112-2124. doi:10.1177/0271678X 16661202

Luo AH, Aston-Jones G. 2009. Circuit projection from suprachiasmatic nucleus to ventral tegmental area: a novel circadian output pathway. Eur I Neurosci 29: 748-760. doi:10.1111/j .1460-9568.2008.06606.x

Macauley SL, Stanley M, Caesar EE, Yamada SA, Raichle ME, Perez R, Mahan TE, Sutphen CL, Holtzman DM. 2015. Hyperglycemia modulates extracellular amyloid- $\beta$ concentrations and neuronal activity in vivo. J Clin Invest 125: 2463-2467. doi:10.1172/JCI79742

Machado NLS, Abbott SBG, Resch JM, Zhu L, Arrigoni E, Lowell BB, Fuller PM, Fontes MAP, Saper CB. 2018. A glutamatergic hypothalamomedullary circuit mediates thermogenesis, but not heat conservation, during stress-induced hyperthermia. Curr Biol 28: 2291-2301 e2295. doi:10.1016/j.cub.2018.05.064

Marchant EG, Watson NV, Mistlberger RE. 1997. Both neuropeptide $\mathrm{Y}$ and serotonin are necessary for entrainment of circadian rhythms in mice by daily treadmill running schedules. I Neurosci 17: 7974-7987. doi:10.1523/JNEUROSCI.17-2007974.1997
Marcheva B, Ramsey KM, Buhr ED, Kobayashi Y, Su H, Ko CH, Ivanova G, Omura C, Mo S, Vitaterna MH, et al. 2010. Disruption of the clock components CLOCK and BMAL1 leads to hypoinsulinaemia and diabetes. Nature 466: 627-631. doi:10 $.1038 /$ nature09253

Mardinly AR, Spiegel I, Patrizi A, Centofante E, Bazinet JE, Tzeng CP, Mandel-Brehm C, Harmin DA, Adesnik H, Fagiolini M, et al. 2016. Sensory experience regulates cortical inhibition by inducing IGF1 in VIP neurons. Nature 531: 371-375. doi:10.1038/nature17187

Maret S, Dorsaz S, Gurcel L, Pradervand S, Petit B, Pfister C, Hagenbuchle O, O'Hara BF, Franken P, Tafti M. 2007. Homerla is a core brain molecular correlate of sleep loss. Proc Natl Acad Sci 104: 20090-20095. doi:10.1073/pnas .0710131104

Maywood ES, Chesham JE, O'Brien JA, Hastings MH. 2011. A diversity of paracrine signals sustains molecular circadian cycling in suprachiasmatic nucleus circuits. Proc Natl Acad Sci 108: 14306-14311. doi:10.1073/pnas.1101767108

Maywood ES, Elliott TS, Patton AP, Krogager TP, Chesham JE, Ernst RJ, Beránek V, Brancaccio M, Chin JW, Hastings MH. 2018. Translational switching of Cryl protein expression confers reversible control of circadian behavior in arrhythmic Cry-deficient mice. Proc Natl Acad Sci 115: E12388E12397. doi:10.1073/pnas.1811438115

McDearmon EL, Patel KN, Ko CH, Walisser JA, Schook AC, Chong JL, Wilsbacher LD, Song EJ, Hong HK, Bradfield CA, et al. 2006. Dissecting the functions of the mammalian clock protein BMAL1 by tissue-specific rescue in mice. Science 314: 1304-1308. doi:10.1126/science.1132430

McGlashan EM, Poudel GR, Vidafar P, Drummond SPA, Cain SW. 2018. Imaging individual differences in the response of the human suprachiasmatic area to light. Front Neurol 9: 1022. doi:10.3389/fneur.2018.01022

McNeill JK IV, Walton JC, Albers HE. 2018. Functional significance of the excitatory effects of GABA in the suprachiasmatic nucleus. I Biol Rhythms 33: 376-387. doi:10.1177/ 0748730418782820

Mendoza J, Graff C, Dardente H, Pevet P, Challet E. 2005. Feeding cues alter clock gene oscillations and photic responses in the suprachiasmatic nuclei of mice exposed to a light/dark cycle. $I$ Neurosci 25: 1514-1522. doi:10.1523/JNEUROSCI.4397-04 .2005

Mermet J, Yeung J, Hurni C, Mauvoisin D, Gustafson K, Jouffe C, Nicolas D, Emmenegger Y, Gobet C, Franken P, et al. 2018. Clock-dependent chromatin topology modulates circadian transcription and behavior. Genes Dev 32: 347-358. doi:10 $.1101 /$ gad.312397.118

Meyer-Bernstein EL, Morin LP. 1996. Differential serotonergic innervation of the suprachiasmatic nucleus and the intergeniculate leaflet and its role in circadian rhythm modulation. I Neurosci 16: 2097-2111. doi:10.1523/JNEUROSCI.16-0602097.1996

Michel S, Itri J, Han JH, Gniotczynski K, Colwell CS. 2006. Regulation of glutamatergic signalling by PACAP in the mammalian suprachiasmatic nucleus. BMC Neurosci 7: 15. doi:10 $.1186 / 1471-2202-7-15$

Mieda M, Ono D, Hasegawa E, Okamoto H, Honma K, Honma S, Sakurai T. 2015. Cellular clocks in AVP neurons of the SCN are critical for interneuronal coupling regulating circadian behavior rhythm. Neuron 85: 1103-1116. doi:10.1016/j .neuron.2015.02.005

Mohawk JA, Green CB, Takahashi JS. 2012. Central and peripheral circadian clocks in mammals. Annu Rev Neurosci 35: 445462. doi:10.1146/annurev-neuro-060909-153128 
Moore RY, Eichler VB. 1972. Loss of a circadian adrenal corticosterone rhythm following suprachiasmatic lesions in the rat. Brain Res 42: 201-206. doi:10.1016/0006-8993(72/90054-6

Moorman DE, Aston-Jones G. 2010. Orexin/hypocretin modulates response of ventral tegmental dopamine neurons to prefrontal activation: diurnal influences. I Neurosci 30: 1558515599. doi:10.1523/JNEUROSCI.2871-10.2010

Moro T, Tinsley G, Bianco A, Marcolin G, Pacelli QF, Battaglia G, Palma A, Gentil P, Neri M, Paoli A. 2016. Effects of eight weeks of time-restricted feeding (16/8) on basal metabolism, maximal strength, body composition, inflammation, and cardiovascular risk factors in resistance-trained males. I Trans 1 Med 14: 290. doi:10.1186/s12967-016-1044-0

Morris ME, Viswanathan N, Kuhlman S, Davis FC, Weitz CJ. 1998. A screen for genes induced in the suprachiasmatic nucleus by light. Science 279: 1544-1547. doi:10.1126/science .279.5356.1544

Mure LS, Le HD, Benegiamo G, Chang MW, Rios L, Jillani N, Ngotho M, Kariuki T, Dkhissi-Benyahya O, Cooper HM, et al. 2018. Diurnal transcriptome atlas of a primate across major neural and peripheral tissues. Science 359.

Murlidharan G, Crowther A, Reardon RA, Song J, Asokan A. 2016. Glymphatic fluid transport controls paravascular clearance of AAV vectors from the brain. JCI Insight 1: e88034. doi:10.1172/jci.insight.88034

Musiek ES, Lim MM, Yang G, Bauer AQ, Qi L, Lee Y, Roh JH, Ortiz-Gonzalez X, Dearborn JT, Culver JP, et al. 2013. Circadian clock proteins regulate neuronal redox homeostasis and neurodegeneration. I Clin Invest 123: 5389-5400. doi:10 $.1172 /$ JCI70317

Nakazato R, Kawabe K, Yamada D, Ikeno S, Mieda M, Shimba S, Hinoi E, Yoneda Y, Takarada T. 2017. Disruption of Bmall impairs blood-brain barrier integrity via pericyte dysfunction. J Neurosci 37: 10052-10062. doi:10.1523/JNEUROSCI.363916.2017

Nath RD, Bedbrook CN, Abrams MJ, Basinger T, Bois JS, Prober DA, Sternberg PW, Gradinaru V, Goentoro L. 2017. The jellyfish cassiopea exhibits a sleep-like state. Curr Biol 27: 29842990.e3. doi:10.1016/j.cub.2017.08.014

Nawathean P, Rosbash M. 2004. The doubletime and CKII kinases collaborate to potentiate Drosophila PER transcriptional repressor activity. Mol Cell 13: 213-223. doi:10.1016/S10972765(03)00503-3

Naylor E, Bergmann BM, Krauski K, Zee PC, Takahashi JS, Vitaterna MH, Turek FW. 2000. The circadian clock mutation alters sleep homeostasis in the mouse. I Neurosci 20: 81388143. doi:10.1523/JNEUROSCI.20-21-08138.2000

Nestler EJ, Peña CJ, Kundakovic M, Mitchell A, Akbarian S. 2016. Epigenetic basis of mental illness. Neuroscientist 22: 447463.

Olson BR, Cartledge T, Sebring N, Defensor R, Nieman L. 1995. Short-term fasting affects luteinizing hormone secretory dynamics but not reproductive function in normal-weight sedentary women. J Clin Endocrinol Metab 80: 1187-1193.

Orozco-Solis R, Ramadori G, Coppari R, Sassone-Corsi P. 2015. SIRT1 relays nutritional inputs to the circadian clock through the Sf1 neurons of the ventromedial hypothalamus. Endocrinology 156: 2174-2184. doi:10.1210/en.2014-1805

Orozco-Solis R, Aguilar-Arnal L, Murakami M, Peruquetti R, Ramadori G, Coppari R, Sassone-Corsi P. 2016. The circadian clock in the ventromedial hypothalamus controls cyclic energy expenditure. Cell Metab 23: 467-478. doi:10.1016/j.cmet .2016.02.003

Otway DT, Mantele S, Bretschneider S, Wright J, Trayhurn P, Skene DJ, Robertson MD, Johnston JD. 2011. Rhythmic diur- nal gene expression in human adipose tissue from individuals who are lean, overweight, and type 2 diabetic. Diabetes 60: 1577-1581. doi:10.2337/db10-1098

Ouyang Y, Andersson CR, Kondo T, Golden SS, Johnson CH. 1998. Resonating circadian clocks enhance fitness in cyanobacteria. Proc Natl Acad Sci 95: 8660-8664. doi:10.1073/ pnas.95.15.8660

Padilla SL, Carmody JS, Zeltser LM. 2010. Pomc-expressing progenitors give rise to antagonistic neuronal populations in hypothalamic feeding circuits. Nat Med 16: 403-405. doi:10 $.1038 / \mathrm{nm} .2126$

Padilla SL, Perez JG, Ben-Hamo M, Johnson CW, Sanchez REA, Bussi IL, Palmiter RD, de la Iglesia HO. 2019. Kisspeptin neurons in the arcuate nucleus of the hypothalamus orchestrate circadian rhythms and metabolism. Curr Biol 29: 592 604.e4. doi:10.1016/j.cub.2019.01.022

Palomares JA, Tummala S, Wang DJ, Park B, Woo MA, Kang DW, St Lawrence KS, Harper RM, Kumar R. 2015. Water exchange across the blood-brain barrier in obstructive sleep apnea: an MRI diffusion-weighted pseudo-continuous arterial spin labeling study. I Neuroimaging 25: 900-905. doi:10.1111/jon .12288

Panda S, Antoch MP, Miller BH, Su AI, Schook AB, Straume M, Schultz PG, Kay SA, Takahashi JS, Hogenesch JB. 2002. Coordinated transcription of key pathways in the mouse by the circadian clock. Cell 109: 307-320. doi:10.1016/S0092-8674(02) 00722-5

Patke A, Murphy PJ, Onat OE, Krieger AC, Özçelik T, Campbell SS, Young MW. 2017. Mutation of the human circadian clock gene CRY1 in familial delayed sleep phase disorder. Cell 169: 203-215.e13. doi:10.1016/j.cell.2017.03.027

Peek CB, Affinati AH, Ramsey KM, Kuo HY, Yu W, Sena LA, Ilkayeva O, Marcheva B, Kobayashi Y, Omura C, et al. 2013. Circadian clock $\mathrm{NAD}^{+}$cycle drives mitochondrial oxidative metabolism in mice. Science 342: 1243417. doi:10.1126/sci ence. 1243417

Pellegrino R, Kavakli IH, Goel N, Cardinale CJ, Dinges DF, Kuna ST, Maislin G, Van Dongen HP, Tufik S, Hogenesch JB, et al. 2014. A novel BHLHE41 variant is associated with short sleep and resistance to sleep deprivation in humans. Sleep 37: 13271336. doi:10.5665/sleep.3924

Perelis M, Marcheva B, Ramsey KM, Schipma MJ, Hutchison AL, Taguchi A, Peek CB, Hong H, Huang W, Omura C, et al. 2015. Pancreatic $\beta$ cell enhancers regulate rhythmic transcription of genes controlling insulin secretion. Science 350: aac4250. doi:10.1126/science.aac4250

Pickard GE. 1982. The afferent connections of the suprachiasmatic nucleus of the golden hamster with emphasis on the retinohypothalamic projection. I Comp Neurol 211: 65-83. doi:10 $.1002 /$ cne.902110107

Pickard GE, Rea MA. 1997. Serotonergic innervation of the hypothalamic suprachiasmatic nucleus and photic regulation of circadian rhythms. Biol Cell 89: 513-523. doi:10.1016/ S0248-4900(98)80007-5

Prolo LM, Takahashi JS, Herzog ED. 2005. Circadian rhythm generation and entrainment in astrocytes. J Neurosci 25: 404-408. doi:10.1523/JNEUROSCI.4133-04.2005

Prosser RA, Bergeron HE. 2003. Leptin phase-advances the rat suprachiasmatic circadian clock in vitro. Neurosci Lett 336: 139-142. doi:10.1016/S0304-3940(02)01234-X

Przewlocki R, Lason W, Konecka AM, Gramsch C, Herz A, Reid LD. 1983. The opioid peptide dynorphin, circadian rhythms, and starvation. Science 219: 71-73. doi:10.1126/science .6129699 
Ramsey KM, Yoshino J, Brace CS, Abrassart D, Kobayashi Y, Marcheva B, Hong HK, Chong JL, Buhr ED, Lee C, et al. 2009. Circadian clock feedback cycle through NAMPT-mediated $\mathrm{NAD}^{+}$biosynthesis. Science 324: 651-654. doi:10.1126/sci ence.1171641

Rea MA, Glass JD, Colwell CS. 1994. Serotonin modulates photic responses in the hamster suprachiasmatic nuclei. J Neurosci 14: 3635-3642. doi:10.1523/JNEUROSCI.14-06-03635 .1994

Reddy AB, Maywood ES, Karp NA, King VM, Inoue Y, Gonzalez FJ, Lilley KS, Kyriacou CP, Hastings MH. 2007. Glucocorticoid signaling synchronizes the liver circadian transcriptome. Hepatology 45: 1478-1488. doi:10.1002/hep.21571

Ren S, Wang Y, Yue F, Cheng X, Dang R, Qiao Q, Sun X, Li X, Jiang $\mathrm{Q}$, Yao J, et al. 2018. The paraventricular thalamus is a critical thalamic area for wakefulness. Science 362: 429-434. doi:10 $.1126 /$ science.aat 2512

Roenneberg T, Allebrandt KV, Merrow M, Vetter C. 2012. Social jetlag and obesity. Curr Biol 22: 939-943. doi:10.1016/j.cub .2012.03.038

Rothschild J, Hoddy KK, Jambazian P, Varady KA. 2014. Time-restricted feeding and risk of metabolic disease: a review of human and animal studies. Nutr Rev 72: 308-318. doi:10.1111/ nure. 12104

Rupp AC, Ren M, Altimus CM, Fernandez DC, Richardson M, Turek F, Hattar S, Schmidt TM. 2019. Distinct ipRGC subpopulations mediate light's acute and circadian effects on body temperature and sleep. Elife 8: e44358. doi:10.7554/ eLife.44358

Rutter J, Reick M, McKnight SL. 2002. Metabolism and the control of circadian rhythms. Annu Rev Biochem 71: 307-331. doi:10.1146/annurev.biochem.71.090501.142857

Saini C, Morf J, Stratmann M, Gos P, Schibler U. 2012. Simulated body temperature rhythms reveal the phase-shifting behavior and plasticity of mammalian circadian oscillators. Genes Dev 26: 567-580. doi:10.1101/gad.183251.111

Saini C, Liani A, Curie T, Gos P, Kreppel F, Emmenegger Y, Bonacina L, Wolf JP, Poget YA, Franken P, et al. 2013. Real-time recording of circadian liver gene expression in freely moving mice reveals the phase-setting behavior of hepatocyte clocks. Genes Dev 27: 1526-1536. doi:10.1101/gad.221374.113

Sakurai T, Amemiya A, Ishii M, Matsuzaki I, Chemelli RM, Tanaka H, Williams SC, Richardson JA, Kozlowski GP, Wilson $\mathrm{S}$, et al. 1998. Orexins and orexin receptors: a family of hypothalamic neuropeptides and $\mathrm{G}$ protein-coupled receptors that regulate feeding behavior. Cell 92: 573-585. doi:10.1016/ S0092-8674(00)80949-6

Samuels MH, Kramer P. 1996. Differential effects of short-term fasting on pulsatile thyrotropin, gonadotropin, and $\alpha$-subunit secretion in healthy men-a clinical research center study. J Clin Endocrinol Metab 81: 32-36.

Saper CB, Lowell BB. 2014. The hypothalamus. Curr Biol 24: R1111-R1116. doi:10.1016/j.cub.2014.10.023

Saper CB, Scammell TE, Lu J. 2005. Hypothalamic regulation of sleep and circadian rhythms. Nature 437: 1257-1263. doi:10 .1038 /nature04284

Schmidt C, Collette F, Leclercq Y, Sterpenich V, Vandewalle G, Berthomier P, Berthomier C, Phillips C, Tinguely G, Darsaud A, et al. 2009. Homeostatic sleep pressure and responses to sustained attention in the suprachiasmatic area. Science 324: 516-519. doi:10.1126/science.1167337

Sheward WJ, Maywood ES, French KL, Horn JM, Hastings MH, Seckl JR, Holmes MC, Harmar AJ. 2007. Entrainment to feeding but not to light: circadian phenotype of VPAC2 receptor- null mice. I Neurosci 27: 4351-4358. doi:10.1523/JNEURO SCI.4843-06.2007

Siepka SM, Yoo SH, Park J, Song W, Kumar V, Hu Y, Lee C, Takahashi JS. 2007. Circadian mutant Overtime reveals F-box protein FBXL3 regulation of cryptochrome and period gene expression. Cell 129: 1011-1023. doi:10.1016/j.cell.2007.04 .030

Silver R, LeSauter J, Tresco PA, Lehman MN. 1996. A diffusible coupling signal from the transplanted suprachiasmatic nucleus controlling circadian locomotor rhythms. Nature 382: 810813. doi:10.1038/382810a0

Spanagel R, Pendyala G, Abarca C, Zghoul T, Sanchis-Segura C, Magnone MC, Lascorz J, Depner M, Holzberg D, Soyka M, et al. 2005. The clock gene Per2 influences the glutamatergic system and modulates alcohol consumption. Nat Med 11:3542. doi: $10.1038 / \mathrm{nm} 1163$

Stenvers DJ, Jongejan A, Atiqi S, Vreijling JP, Limonard EJ, Endert E, Baas F, Moerland PD, Fliers E, Kalsbeek A, et al. 2019. Diurnal rhythms in the white adipose tissue transcriptome are disturbed in obese individuals with type 2 diabetes compared with lean control individuals. Diabetologia 62: 704-716. doi:10.1007/s00125-019-4813-5

Stephan FK, Zucker I. 1972. Circadian rhythms in drinking behavior and locomotor activity of rats are eliminated by hypothalamic lesions. Proc Natl Acad Sci 69: 1583-1586. doi:10.1073/pnas.69.6.1583

Stokkan KA, Yamazaki S, Tei H, Sakaki Y, Menaker M. 2001. Entrainment of the circadian clock in the liver by feeding. Science 291: 490-493. doi:10.1126/science.291.5503.490

Storch KF, Weitz CJ. 2009. Daily rhythms of food-anticipatory behavioral activity do not require the known circadian clock. Proc Natl Acad Sci 106: 6808-6813. doi:10.1073/pnas .0902063106

Strubbe JH, Prins AJ, Bruggink J, Steffens AB. 1987. Daily variation of food-induced changes in blood glucose and insulin in the rat and the control by the suprachiasmatic nucleus and the vagus nerve. I Auton Nerv Syst 20: 113-119. doi:10 .1016/0165-1838/87)90108-1

Sutton GM, Perez-Tilve D, Nogueiras R, Fang J, Kim JK, Cone RD, Gimble JM, Tschop MH, Butler AA. 2008. The melanocortin-3 receptor is required for entrainment to meal intake. J Neurosci 28: 12946-12955. doi:10.1523/JNEUROSCI.361508.2008

Sutton EF, Beyl R, Early KS, Cefalu WT, Ravussin E, Peterson CM. 2018. Early time-restricted feeding improves insulin sensitivity, blood pressure, and oxidative stress even without weight loss in men with prediabetes. Cell Metab 27: 12121221.e3. doi:10.1016/j.cmet.2018.04.010

Syd U. 1997. The seven deadly curs'd sins ... lust. Curr Biol 7: R664. doi:10.1016/S0960-9822(06)00344-7

Tabuchi M, Monaco JD, Duan G, Bell B, Liu S, Liu Q, Zhang K, Wu MN. 2018. Clock-generated temporal codes determine synaptic plasticity to control sleep. Cell 175: 1213-1227.e18. doi:10.1016/j.cell.2018.09.016

Takahashi JS. 2017. Transcriptional architecture of the mammalian circadian clock. Nat Rev Genet 18: 164-179. doi:10.1038/ nrg.2016.150

Tan CL, Cooke EK, Leib DE, Lin YC, Daly GE, Zimmerman CA, Knight ZA . 2016. Warm-sensitive neurons that control body temperature. Cell 167: 47-59.e15. doi:10.1016/j.cell.2016.08 .028

Taoka T, Jost G, Frenzel T, Naganawa S, Pietsch H. 2018. Impact of the glymphatic system on the kinetic and distribution of gadodiamide in the rat brain: observations by dynamic MRI and Effect of circadian rhythm on tissue gadolinium 
concentrations. Invest Radiol 53: 529-534. doi:10.1097/RLI .0000000000000473

Thompson CL, Sancar A. 2002. Photolyase/cryptochrome bluelight photoreceptors use photon energy to repair DNA and reset the circadian clock. Oncogene 21: 9043-9056. doi:10 .1038/sj.onc. 1205958

Toh KL, Jones CR, He Y, Eide EJ, Hinz WA, Virshup DM, Ptacek LJ, Fu YH. 2001. An hPer2 phosphorylation site mutation in familial advanced sleep phase syndrome. Science 291: 10401043. doi:10.1126/science.1057499

Tso CF, Simon T, Greenlaw AC, Puri T, Mieda M, Herzog ED. 2017. Astrocytes regulate daily rhythms in the suprachiasmatic nucleus and behavior. Curr Biol 27: 1055-1061. doi:10 $.1016 /$ j.cub.2017.02.037

Tuomi T, Nagorny CLF, Singh P, Bennet H, Yu Q, Alenkvist I, Isomaa B, Ostman B, Söderström J, Pesonen AK, et al. 2016. Increased melatonin signaling is a risk factor for type 2 diabetes. Cell Metab 23: 1067-1077. doi:10.1016/j.cmet .2016 .04 .009

Turek FW, Joshu C, Kohsaka A, Lin E, Ivanova G, McDearmon E, Laposky A, Losee-Olson S, Easton A, Jensen DR, et al. 2005. Obesity and metabolic syndrome in circadian Clock mutant mice. Science 308: 1043-1045. doi:10.1126/science.1108750

van der Vinne V, Riede SJ, Gorter JA, Eijer WG, Sellix MT, Menaker M, Daan S, Pilorz V, Hut RA. 2014. Cold and hunger induce diurnality in a nocturnal mammal. Proc Nat1 Acad Sci 111: 15256-15260. doi:10.1073/pnas.1413135111

Venkatesh B, Si-Hoe SL, Murphy D, Brenner S. 1997. Transgenic rats reveal functional conservation of regulatory controls between the Fugu isotocin and rat oxytocin genes. Proc Natl Acad Sci 94: 12462-12466. doi:10.1073/pnas.94.23.12462

Vimal RL, Pandey-Vimal MU, Vimal LS, Frederick BB, Stopa EG, Renshaw PF, Vimal SP, Harper DG. 2009. Activation of suprachiasmatic nuclei and primary visual cortex depends upon time of day. Eur J Neurosci 29: 399-410. doi:10.1111/j.14609568.2008.06582.x

Viola AU, Archer SN, James LM, Groeger JA, Lo JC, Skene DJ, von Schantz M, Dijk DJ. 2007. PER3 polymorphism predicts sleep structure and waking performance. Curr Biol 17: 613-618. doi:10.1016/j.cub.2007.01.073

von Gall C, Duffield GE, Hastings MH, Kopp MD, Dehghani F, Korf HW, Stehle JH. 1998. CREB in the mouse SCN: a molecular interface coding the phase-adjusting stimuli light, glutamate, PACAP, and melatonin for clockwork access. J Neurosci 18: 10389-10397. doi:10.1523/JNEUROSCI.18-2410389.1998

Wang TA, Yu YV, Govindaiah G, Ye X, Artinian L, Coleman TP, Sweedler JV, Cox CL, Gillette MU. 2012. Circadian rhythm of redox state regulates excitability in suprachiasmatic nucleus neurons. Science 337: 839-842. doi:10.1126/science .1222826

Wang JL, Lim AS, Chiang WY, Hsieh WH, Lo MT, Schneider JA, Buchman AS, Bennett DA, Hu K, Saper CB. 2015. Suprachiasmatic neuron numbers and rest-activity circadian rhythms in older humans. Ann Neurol 78: 317-322. doi:10.1002/ana .24432

Wang Q, Abruzzi KC, Rosbash M, Rio DC. 2018. Striking circadian neuron diversity and cycling of Drosophila alternative splicing. Elife 7: e35618. doi:10.7554/eLife.35618

Watts AG, Swanson LW. 1987. Efferent projections of the suprachiasmatic nucleus: II. Studies using retrograde transport of fluorescent dyes and simultaneous peptide immunohistochemistry in the rat. I Comp Neurol 258: 230-252. doi:10 $.1002 /$ cne.902580205
Watts AG, Swanson LW. 1989. Diurnal variations in the content of preprocorticotropin-releasing hormone messenger ribonucleic acids in the hypothalamic paraventricular nucleus of rats of both sexes as measured by in situ hybridization. Endocrinology 125: 1734-1738. doi:10.1210/endo-125-3-1734

Williams KW, Margatho LO, Lee CE, Choi M, Lee S, Scott MM, Elias CF, Elmquist JK. 2010. Segregation of acute leptin and insulin effects in distinct populations of arcuate proopiomelanocortin neurons. I Neurosci 30: 2472-2479. doi:10.1523/ JNEUROSCI.3118-09.2010

Wisor JP, O'Hara BF, Terao A, Selby CP, Kilduff TS, Sancar A, Edgar DM, Franken P. 2002. A role for cryptochromes in sleep regulation. BMC Neurosci 3: 20. doi:10.1186/14712202-3-20

Womac AD, Burkeen JF, Neuendorff N, Earnest DJ, Zoran MJ. 2009. Circadian rhythms of extracellular ATP accumulation in suprachiasmatic nucleus cells and cultured astrocytes. Eur I Neurosci 30: 869-876. doi:10.1111/j.1460-9568.2009 $.06874 . \mathrm{x}$

Xie L, Kang H, Xu Q, Chen MJ, Liao Y, Thiyagarajan M, O'Donnell J, Christensen DJ, Nicholson C, Iliff JJ, et al. 2013. Sleep drives metabolite clearance from the adult brain. Science 342: 373-377. doi:10.1126/science.1241224

Yan L, Smale L, Nunez AA. 2018. Circadian and photic modulation of daily rhythms in diurnal mammals. Eur I Neurosci doi:10.1111/ejn.14172

Yannielli PC, Molyneux PC, Harrington ME, Golombek DA. 2007. Ghrelin effects on the circadian system of mice. I Neurosci 27: 2890-2895. doi:10.1523/JNEUROSCI.3913-06 .2007

Yap E-L, Greenberg ME. 2018. Activity-regulated transcription: bridging the gap between neural activity and behavior. Neuron 100: 330-348. doi:10.1016/j.neuron.2018.10.013

Yelin-Bekerman L, Elbaz I, Diber A, Dahary D, Gibbs-Bar L, Alon S, Lerer-Goldshtein T, Appelbaum L. 2015. Hypocretin neuron-specific transcriptome profiling identifies the sleep modulator Kcnh4a. Elife 4: e08638. doi:10.7554/eLife .08638

Yi CX, Challet E, Pévet P, Kalsbeek A, Escobar C, Buijs RM. 2008. A circulating ghrelin mimetic attenuates light-induced phase delay of mice and light-induced Fos expression in the suprachiasmatic nucleus of rats. Eur I Neurosci 27: 1965-1972. doi:10.1111/j.1460-9568.2008.06181.x

Yoo SH, Mohawk JA, Siepka SM, Shan Y, Huh SK, Hong HK, Kornblum I, Kumar V, Koike N, Xu M, et al. 2013. Competing E3 ubiquitin ligases govern circadian periodicity by degradation of CRY in nucleus and cytoplasm. Cell 152: 1091-1105. doi:10.1016/j.cell.2013.01.055

Yuan XS, Wei HH, Xu W, Wang L, Qu WM, Li RX, Huang ZL. 2018. Whole-brain monosynaptic afferent projections to the cholecystokinin neurons of the suprachiasmatic nucleus. Front Neurosci 12: 807. doi:10.3389/fnins.2018.00807

Zhang X, van den Pol AN. 2017. Rapid binge-like eating and body weight gain driven by zona incerta GABA neuron activation. Science 356: 853-859. doi:10.1126/science.aam7100

Zhang Y, Ling J, Yuan C, Dubruille R, Emery P. 2013. A role for Drosophila ATX2 in activation of PER translation and circadian behavior. Science 340: 879-882. doi:10.1126/science .1234746

Zhang J, Zhu Y, Zhan G, Fenik P, Panossian L, Wang MM, Reid S, Lai D, Davis JG, Baur JA, et al. 2014a. Extended wakefulness: compromised metabolics in and degeneration of locus ceruleus neurons. I Neurosci 34: 4418-4431. doi:10.1523/JNEURO SCI.5025-12.2014 
Zhang R, Lahens NF, Ballance HI, Hughes ME, Hogenesch JB. 2014b. A circadian gene expression atlas in mammals: implications for biology and medicine. Proc Natl Acad Sci 111: 16219-16224. doi:10.1073/pnas.1408886111

Zhang Y, Fang B, Emmett MJ, Damle M, Sun Z, Feng D, Armour SM, Remsberg JR, Jager J, Soccio RE, et al. 2015. Gene regulation. Discrete functions of nuclear receptor Rev-erba couple metabolism to the clock. Science 348: 1488-1492. doi:10 $.1126 /$ science.aab3021

Zhang SL, Yue Z, Arnold DM, Artiushin G, Sehgal A. 2018. A circadian clock in the blood-brain barrier regulates xenobiotic efflux. Cell 173: 130-139.e10. doi:10.1016/j.cell.2018.02.017
Zheng X, Sehgal A. 2010. AKT and TOR signaling set the pace of the circadian pacemaker. Curr Biol 20: 1203-1208. doi:10 .1016/j.cub.2010.05.027

Zhou L, Bryant CD, Loudon A, Palmer AA, Vitaterna MH, Turek FW. 2014. The circadian clock gene Csnk1e regulates rapid eye movement sleep amount, and nonrapid eye movement sleep architecture in mice. Sleep 37: 785-793. 793A-793C. doi:10.5665/sleep.3590

Zimmerman CA, Lin YC, Leib DE, Guo L, Huey EL, Daly GE, Chen Y, Knight ZA. 2016. Thirst neurons anticipate the homeostatic consequences of eating and drinking. Nature 537: 680-684. doi:10.1038/nature18950 


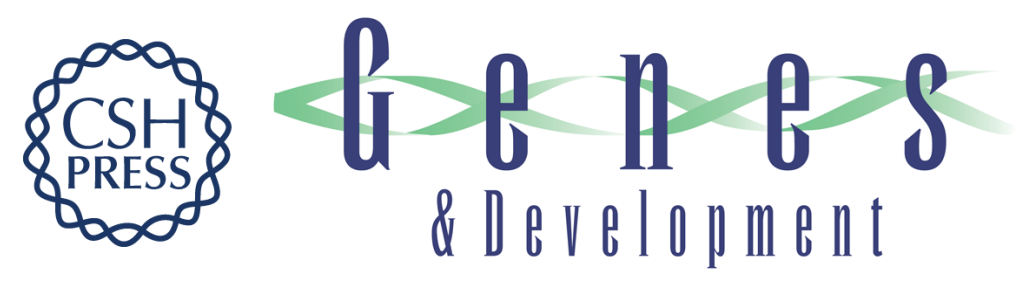

\section{Neurogenetic basis for circadian regulation of metabolism by the hypothalamus}

Jonathan Cedernaes, Nathan Waldeck and Joseph Bass

Genes Dev. 2019, 33:

Access the most recent version at doi:10.1101/gad.328633.119

$\begin{aligned} & \text { References } \begin{array}{l}\text { This article cites } 268 \text { articles, } 88 \text { of which can be accessed free at: } \\ \text { http://genesdev.cshlp.org/content/33/17-18/1136.full.html\#ref-list-1 }\end{array} \\ & \begin{aligned} \text { Creative } \\ \text { Commons } \\ \text { License }\end{aligned} \begin{array}{l}\text { This article is distributed exclusively by Cold Spring Harbor Laboratory Press for the first } \\ \text { six months after the full-issue publication date (see } \\ \text { http://genesdev.cshlp.org/site/misc/terms.xhtml). After six months, it is available under a } \\ \text { Creative Commons License (Attribution-NonCommercial } 4.0 \text { International), as described } \\ \text { at http://creativecommons.org/licenses/by-nc/4.0/. }\end{array} \\ & \begin{array}{c}\text { Receive free email alerts when new articles cite this article - sign up in the box at the top } \\ \text { right corner of the article or click here. }\end{array} \\ & \begin{array}{c}\text { Alerting } \\ \text { Service }\end{array}\end{aligned}$

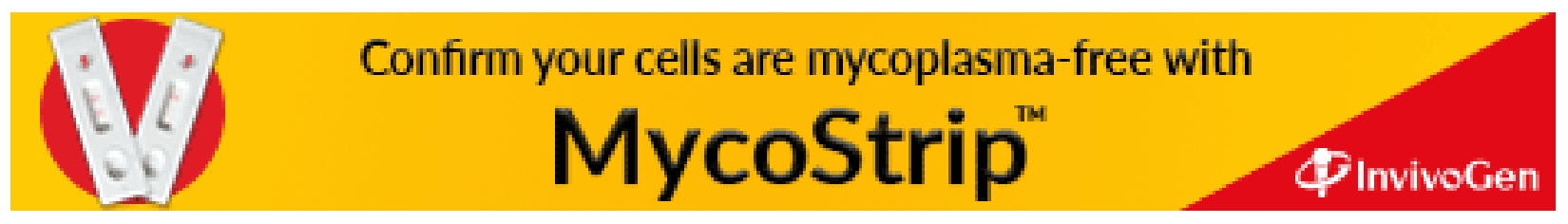

